\title{
Broad phenotypic alterations and potential dysfunctions of lymphocytes in COVID-19 recovered individuals
}

Jingyi Yang ${ }^{1,2,3, *}$, Maohua Zhong ${ }^{1,2,3, *}$, Ejuan Zhang ${ }^{1,2,3, *}$, Ke Hong ${ }^{3,4, *}$, Qingyu Yang ${ }^{2,3,4}$, Dihan Zhou ${ }^{1,2}$, Jianbo Xia ${ }^{5}$, Yao-Qing Chen ${ }^{6}$, Mingbo Sun ${ }^{7}$, Bali Zhao ${ }^{2,8}$, Jie Xiang ${ }^{3,4}$, Ying Liu ${ }^{4,9}$, Yang Han $^{2,3,4}$, Xi Zhou $^{1,2,3,8,} \uparrow$, Chaolin Huang ${ }^{3,4,} \uparrow$, You Shang ${ }^{3,4,10,} \uparrow$, Huimin Yan $^{1,2,3,8,11,} \dagger$

1 Joint Laboratory of Infectious Diseases and Health, Wuhan Institute of Virology \& Wuhan Jinyintan Hospital, Wuhan Institute of Virology, Center for Biosafety Mega-Science, Chinese Academy of Sciences (CAS), Wuhan, Hubei 430023 China

2 State Key Laboratory of Virology, Wuhan Institute of Virology, Center for Biosafety Mega-Science, CAS, Wuhan, Hubei 430071, China

3 Center for Translational Medicine, Jinyintan Hospital, Wuhan, Hubei 430023 China

4 Joint Laboratory of Infectious Diseases and Health, Wuhan Institute of Virology \& Wuhan Jinyintan Hospital, Wuhan Jinyintan Hospital, Wuhan, Hubei 430023 China

5 Department of Laboratory Medicine, Maternal and Child Health Hospital of Hubei Province, Tongji Medical College, Huazhong University of Science and Technology, Wuhan, Hubei 430070 China 6 School of Public Health (Shenzhen), Sun Yat-sen University, Guangzhou, P. R. China

7 Institute of Medical Biology, Chinese Academy of Medical Sciences \& Peking Union Medical College

8 University of Chinese Academy of Sciences, Beijing 100049 China

9 The Office of Drug Clinical Trial Institution, Jinyintan Hospital, Wuhan, Hubei 430023 China

10 Department of Critical Care Medicine, Union Hospital, Tongji Medical College, Huazhong University of Science and Technology, Wuhan, Hubei 430030 China

11 Lead Contact

*Contributed equally

† Correspondence: hmyan@wh.iov.cn (H.Y.), you_shanghust@163.com (Y.S.), 88071718@qq.com (C.H.), zhouxi@wh.iov.cn (X.Z.) 
medRxiv preprint doi: https://doi.org/10.1101/2020.07.01.20144030; this version posted July 2,2020 . The copyright holder for this preprint (which was not certified by peer review) is the author/funder, who has granted medRxiv a license to display the preprint in perpetuity.

All rights reserved. No reuse allowed without permission.

\section{Summary}

2 Background Lymphopenia is a typical symptom in the COVID-19 patients. While millions of patients 3 are clinical recovered, little is known about the immune status of lymphocytes in these individuals.

4 Methods A clinical recovered cohort (CR) of 55 COVID-19 individuals (discharged from hospital 4 to

511 weeks), and 55 age and sex matched healthy donors cohort (HD) were recruited. Detailed analysis

6 on phenotype of the lymphocytes in peripheral blood mononuclear cells (PBMCs) was performed by 7 flow cytometry.

8 Findings Compared with cohort $\mathrm{HD}$, the $\mathrm{CD} 8^{+} \mathrm{T}$ cells in cohort $\mathrm{CR}$ had higher Teff and Tem, but lower Tc1 $\left(\mathrm{IFN}-\gamma^{+}\right), \mathrm{Tc} 2\left(\mathrm{IL}-4^{+}\right)$and Tc17 (IL-17A $\left.{ }^{+}\right)$frequencies. The $\mathrm{CD} 4^{+} \mathrm{T}$ cells of $\mathrm{CR}$ had decreased frequency, especially on the $\mathrm{Tcm}$ subset. Moreover, $\mathrm{CD} 4^{+} \mathrm{T}$ cells of $\mathrm{CR}$ expressed lower

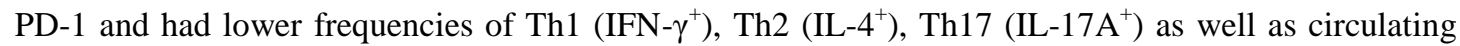
Tfh $\left(\mathrm{CXCR}^{+} \mathrm{PD}-1^{+}\right)$. Accordingly, isotype-switched memory B cell $\left(\operatorname{IgMCD} 20^{\mathrm{hi}}\right)$ in $\mathrm{CR}$ had significantly lower proportion in B cells, though level of activation marker CD71 elevated. For CD3'HLA-DR ${ }^{\text {lo }}$ lymphocytes of CR, besides levels of IFN- $\gamma$, Granzyme B and T-bet were lower, the correlation between T-bet and IFN- $\gamma$ became irrelevant. In addition, taken into account of discharged days, all the lowered function associated phenotypes showed no recovery tendency within whole observation period.

Interpretation The CR COVID-19 individuals still showed remarkable phenotypic alterations in lymphocytes after clinical recovery 4 to 11 weeks. This suggests SARS-CoV-2 infection imprints profoundly on lymphocytes and results in long-lasting potential dysfunctions.

Funding Kunming Science and Technology Department (2020-1-N-037) 


\section{Introduction}

The worldwide pandemic of COVID-19 caused by SARS-CoV-2 has become global threat to human and society though the epidemic subsided after control measures were taken in China. As of Jun 30, 2020, there were more than 10 million confirmed infections globally, in more than 180 countries, with more than 500,000 deaths, and about 5.6 million clinical recovered. Lymphocytes are critical for eliminating infection and for establishment of long-term immunity. ${ }^{1-3}$ However, lymphopenia was reported as a typical clinical symptom in COVID-19 patients besides the specific peripheral ground-glass opacities lung consolidation. ${ }^{4,5} \mathrm{~A}$ growing of studies have reported decrease number and impaired function of $\mathrm{CD}^{+} \mathrm{T}, \mathrm{CD} 8^{+} \mathrm{T}$ and NK cells in COVID-19 patients, especially in severe COVID-19 cases. ${ }^{6-11}$ Although lymphocyte count could gradually elevate to normal range in some patients in blood after viral clearance and clinical recovery, ${ }^{7,12}$ the activation, differentiation and function of lymphocytes in the clinical recovered COVID-19 subjects remain poorly understood. In a follow-up study of an asymptomatic infected case without lymphopenia, we found IFN- $\gamma^{+} \mathrm{CD} 8^{+} \mathrm{T}$ cells and $\mathrm{IL}-17 \mathrm{~A}^{+} \mathrm{CD}^{+} \mathrm{T}$ cells were still detained at a remarkable lower percentages, even when SARS-CoV-2 virus had become undetectable for three weeks. ${ }^{13}$ These results whistle that SARS-CoV-2 may persistently affect the immune system. Despite the large numbers of recovered populations, there is a scarcity of information on the composition, phenotype and function potential of the lymphocytes. In this study, we comprehensively investigated the lymphocyte phenotype and potential function of a clinical recovered COVID-19 cohort (CR) recruited in Wuhan by comparative analyzing the peripheral blood nonnuclear cells (PBMCs) with age \& sex matched uninfected healthy donors (HD).

\section{Methods}

\section{Study design and participants}

We did a cohort study on individuals aged 25-70 years in Wuhan Jinyintan Hospital in April 2020. We collected peripheral blood nonnuclear cells (PBMCs) from 72 COVID-19 recovered individuals who were recruited for physical reexamination after discharge at least 4 weeks, and from 57 healthy donors control who were recruited for regular physical examination.

Clinical recovered COVID-19 individuals with virus re-detected positive ( 3 persons), and individuals with both SARS-CoV-2 RBD specific IgM and IgG negative in plasma (13 persons), were excluded. Healthy donors were enrolled and confirmed without on-going or past SARS-CoV-2 infection, based on nucleotide acid assay of nasopharyngeal swab samples and SARS-CoV-2 RBD specific IgM and IgG assays of plasma (2 persons excluded). The individuals who had series chronic problem such as HIV, HCV infection, cerebrovascular disease, kidney disease were also excluded (1 Clinical recovered COVID-19 individual).

After exclusion, a cohort of fifty-five healthy donors (HD, 23 male and 32 female, mean age 49.1, median age 51) and a fifty-five clinical recovered COVID-19 cohort (CR, 21 male and 34 female, mean age $48 \cdot 8$, median age 51) were involved in the study (supplement table 1), except the cases for assay on Tfh, B cells and cytokines IL-2, in which a sub-cohort of only 36 clinical recovered individuals (14 male and 22 female, mean age 50.6, median age 52) was involved in due to lack of antibody reagents.

This study was reviewed and approved by the Medical Ethical Committee of Wuhan Jinyintan hospital (approval number KY-2020-47.01). Written informed consent was obtained from the COVID-19 recovered individuals and the healthy donors.

\section{Clinical laboratory measurements}


Clinical laboratory measurements, antibody detection were performed in Wuhan Jinyintan Hospital in April, 2020. Nasopharyngeal swab samples were collected on the day of peripheral blood collection and were tested by qRT-PCR for amplification of E gene, RdRp gene, and $\mathrm{N}$ gene of SARS-CoV-2 as described by our previous study. ${ }^{14}$

Clinical laboratory investigation was performed, including series of complete blood count, physical examination and etc (supplementary table 1).

\section{Lymphocyte responses evaluation by flow cytometry}

Plasma and cell pellets were separated from fresh peripheral blood from the clinical recovered COVID-19 individuals and healthy donors. Plasma was used for detection of SARS-CoV-2 binding IgM or IgG. PBMCs were separated from the cell pellets after resuspension with PBS by density gradient centrifugation and resuspended in complete RPMI1640 medium containing 10\% FBS (Gibco), $1 \%$ penicillin and $1 \%$ streptomycin.

For phenotypical analysis of lymphocytes, PBMCs were staining directly. For functional assay of lymphocytes, PBMCs were stimulated with $200 \mathrm{ng} / \mathrm{ml}$ PMA (Beyotime, China), $2.5 \mu \mathrm{M}$ ionomycin (Beyotime, China) in the presence of $1 \mu \mathrm{M}$ monensin (BioLegend, USA) and $2.5 \mu \mathrm{g} / \mathrm{ml}$ Brefeldin A at $37^{\circ} \mathrm{C}, 5 \% \mathrm{CO}_{2}$ for $4.5 \mathrm{~h}$ before staining. PBMCs were stained with dead cell discrimination marker (eBioscience ${ }^{\mathrm{TM}}$ Fixable Viability Dye eFluor ${ }^{\mathrm{TM}} 506$ ) and a panel of surface mAbs in PBS at $4^{\circ} \mathrm{C}$ for 30 min. After washed by PBS, cells were fixed with fixation/permeabilization buffer (eBioscience) at $4^{\circ} \mathrm{C}$ overnight, and then stained with the respective panel of intracellular markers in a permeabilization buffer at $4{ }^{\circ} \mathrm{C}$ for $30 \mathrm{~min}$. Antibodies used in this study were all from BioLegend (USA) and listed in supplementary table S2. A BD LSR Fortessa flow cytometer (Becton Dickinson) was used to assess the stained cells. Data was analyzed using FlowJo V7.0.

\section{Statistical analysis}

Data are presented as means $\pm \mathrm{SD}$. All data analyses were performed with unpaired 2-tailed Student's t-test or Liner Regression. Statistical analysis was carried out with InStat, version 8.0 (GraphPad Software, La Jolla, CA, USA). P $<0.05$ was considered significant.

\section{Role of the funding source}

The funding agencies did not participate in study design, data collection, data analysis, or writing of the report. The corresponding authors were responsible for all aspects of the study to ensure that issues related to the accuracy or integrity of any part of the work were properly investigated and resolved. The final version was approved by all authors.

\section{Results}

On the day of sample collection and assay, all subjects of CR were in normal oxygen saturation over 95\% by clinical examination (Supplementary Table S1). The majority of CR individuals presented no symptoms in the past two weeks, except four experienced shod of breath, six experienced cough, three experienced expectoration, and one experienced oxygen uptake.

All the $55 \mathrm{CR}$ individuals had normal counts of total lymphocytes, except one showed remarkable lymphopenia $\left(0 \cdot 64 * 10^{7} / \mathrm{ml}\right)$ (supplementary table $\mathrm{S} 1$ ). Lymphocyte populations, including $\mathrm{CD}^{+} \mathrm{T}$ cells, $\mathrm{CD}^{+} \mathrm{T}$ cells, $\mathrm{CD} 3^{-\mathrm{CD}} 19^{+} \mathrm{B}$ cells, and non-T non-B CD3 ${ }^{-} \mathrm{HLA}^{-} \mathrm{DR}^{\mathrm{lo}}$ subset were analyzed (figure 1A). To our surprise, percentage of $\mathrm{CD} 4^{+} \mathrm{T}$ cells in the lymphocytes of $\mathrm{CR}$ cohort was statistically lower than that in the healthy donors (HD), though the percentage of $\mathrm{CD}^{+} \mathrm{T}$ cells, B cells or CD3 $\mathrm{HLA}^{-} \mathrm{DR}^{\text {lo }}$ lymphocytes in the lymphocytes of CR cohort was already comparable to that of HD (figure 1B). We then assayed and analyzed the differentiation, activation, proliferation and potential function of the four 
lymphocyte subsets one by one.

In the context of $\mathrm{CD}^{+} \mathrm{T}$ cells, the frequencies of both effector $\mathrm{T}$ cells $\left(\mathrm{CD} 45 \mathrm{RO}^{-} \mathrm{CD} 27^{-}\right.$, Teff) and effector memory $\mathrm{T}$ cells $\left(\mathrm{CD} 45 \mathrm{RO}^{+} \mathrm{CD} 27^{-}, \mathrm{Tem}\right)$ of $\mathrm{CR}$ were significantly higher than that of $\mathrm{HD}$, while the frequency of $\mathrm{CR}$ naive $\mathrm{T}$ cells $\left(\mathrm{CD} 45 \mathrm{RO}^{-} \mathrm{CD} 27^{+}\right.$, Tna) and central memory $\mathrm{T}$ cells $\left(\mathrm{CD}_{5} 5 \mathrm{RO}^{+} \mathrm{CD} 27^{+}, \mathrm{Tcm}\right)$ were lower than that of $\mathrm{HD}$ (figure $2 \mathrm{~A}$ ). This indicated significant differentiation occurred in $\mathrm{CD}^{+} \mathrm{T}$ cells post SARS-CoV-2 infection. In terms of activation, HLA-DR and PD-1 of CR cohort were similar as those of HD (figure 2B and S1A, S1B), indicating CD8 ${ }^{+} \mathrm{T}$ cells in $\mathrm{CR}$ nearly recovered into normal level, although with a slightly higher proliferation activity indicated by $\mathrm{Ki}-67^{+}$in $\mathrm{Tcm}$ subsets (figure $2 \mathrm{C}$ and $\mathrm{S1C}$ ). Then, functions of $\mathrm{CD} 8^{+} \mathrm{T}$ cells were analyzed under polyclonal stimulation. Intriguingly, although frequencies of $\mathrm{IL}^{2} 2^{+}$and Granzyme B $(\mathrm{GZMB})^{+} \mathrm{CD} 8^{+} \mathrm{T}$ cells showed no difference between $\mathrm{CR}$ and $\mathrm{HD}$ (figure 2D), the frequency of IFN $-\gamma^{+}$ in $\mathrm{CD}^{+} \mathrm{T}$ cells $(\mathrm{Tc} 1)$ of $\mathrm{CR}$ was notably reduced compared with that of $\mathrm{HD}$ (figure $2 \mathrm{E}$ ). However, T-bet expression on $\mathrm{CD}^{+} \mathrm{T}$ cells of $\mathrm{CR}$ was not reduced and the correlation between T-bet ${ }^{+}$and IFN- $\gamma^{+}$ remained (figure 2F). Further analysis showed that proportions of IFN- $\gamma^{+} \mathrm{IL}_{-2}^{-}$and IFN $-\gamma^{+} \mathrm{GZMB}^{-}$in $\mathrm{CR}$ cohort were significantly reduced, while IFN- $\gamma^{-\mathrm{GZMB}^{+}}$remarkably increased compared to HD (figure $2 \mathrm{G}$ ). Besides, frequencies of both IL- $4^{+} \mathrm{CD} 8^{+} \mathrm{T}$ cells (Tc2) and IL-17A $\mathrm{A}^{+} \mathrm{CD} 8^{+} \mathrm{T}$ cells (Tc17) in CR were significantly reduced (figure $2 \mathrm{H}$ and I). Moreover, $\mathrm{Tc} 1, \mathrm{Tc} 2$ and $\mathrm{Tc} 17$ in $\mathrm{CR}$, consistently deviated from HD and showed no tendency to recover with the increased days post clinical discharge (figure 2E, $\mathrm{H}$ and I). The data suggested remarkable repression on $\mathrm{CD} 8^{+} \mathrm{T}$ cells of $\mathrm{CR}$ was long-lasting, though activation, proliferation and differentiation might be normal.

In the context of $\mathrm{CD}^{+} \mathrm{T}$ cells, the frequency of Teff, Tem or naïve $\mathrm{T}$ cells of $\mathrm{CR}$ cohort showed no change, but Tcm was remarkably reduced compared to HD (figure 3A), suggesting an aberrant $\mathrm{CD}^{+} \mathrm{T}$ cell differentiation post SARS-CoV-2 infection. In terms of activation, HLA-DR on CD4 ${ }^{+} \mathrm{T}$ cells of $\mathrm{CR}$ and $\mathrm{HD}$ also showed no difference, though $\mathrm{HLA}^{-\mathrm{DR}^{+}}$in naïve $\mathrm{CD} 4^{+} \mathrm{T}$ cells of $\mathrm{CR}$ was significantly lower (figure 3B and S2A). However, PD- $1^{+}$was remarkably lower in all $\mathrm{CD}^{+}{ }^{+} \mathrm{T}$ cell subsets of $\mathrm{CR}$ (figure 3B and S2B), indicating a significant repression of the $\mathrm{CD} 4^{+} \mathrm{T}$ cell activation in CR. The proliferation indicated by Ki-67 showed no difference between CR and HD (figure 3C) though $\mathrm{Ki}-67^{+}$in Tcm subset of CR was slightly higher (figure S2C). Function analysis under polyclonal stimulation showed the frequency of IFN- $\gamma^{+}$in $\mathrm{CD} 4^{+} \mathrm{T}$ cells (Th1) of $\mathrm{CR}$ was notably lower than that of $\mathrm{HD}$ (figure 3E), though the frequencies of $\mathrm{IL}_{-} 2^{+}$and $\mathrm{GZMB}^{+} \mathrm{CD}^{+} \mathrm{T}$ cell showed no difference between $\mathrm{CR}$ and $\mathrm{HD}$ (figure 3D). Similar as $\mathrm{CD} 8^{+} \mathrm{T}$ cells, $\mathrm{T}$-bet in $\mathrm{CD} 4^{+} \mathrm{T}$ cells of $\mathrm{CR}$ was not reduced either and the correlation between T-bet ${ }^{+}$and IFN- $\gamma^{+}$also remained (figure $3 \mathrm{~F}$ ). In more detail, the proportions of IFN $-\gamma^{+} \mathrm{IL}_{-2} 2^{+}$and IFN- $\gamma^{+} \mathrm{GZMB}^{-}$of $\mathrm{CR}$ were significantly reduced, but IFN- $\gamma^{-} \mathrm{GZMB}^{+}$ remarkably increased in $\mathrm{CD} 4^{+} \mathrm{T}$ cells of $\mathrm{CR}$ (figure $3 \mathrm{G}$ ). However, the frequencies of $\mathrm{IL}-4^{+} \mathrm{CD} 4^{+} \mathrm{T}$ cell (Th2) and IL-17 $\mathrm{A}^{+} \mathrm{CD} 4^{+} \mathrm{T}$ cell (Th17) of CR (figure $3 \mathrm{H}$ and I) were both reduced significantly, indicating the functions of Th2 and Th17 were somehow repressed. Percentages of CXCR $3^{+}$and $\mathrm{CCR}^{+}$, which could present $\mathrm{Th} 1$ and Th17 cells respectively, were also highly reduced in $\mathrm{CD} 4^{+} \mathrm{T}$ cells of CR (figure S2D and 2E), indicating the frequencies of Th1 and Th17 were persistently and remarkably reduced in CR.

$\mathrm{T}$ follicular helper (Tfh), with CXCR5 as a marker, is the specialized subset of $\mathrm{CD} 4^{+} \mathrm{T}$ cells needed for germinal centers and related $\mathrm{B}$ cell responses. ${ }^{15}$ In line with the frequency of $\mathrm{CXCR}^{+}$and $\mathrm{CCR}^{+}$, that of $\mathrm{CXCR5}^{+}$in $\mathrm{CD}^{+}{ }^{+} \mathrm{T}$ cells of $\mathrm{CR}$ was also much lower than that of $\mathrm{HD}$ (figure $\mathrm{S} 2 \mathrm{~F}$ ). Accordingly, the frequency of circulating $\mathrm{Tfh}\left(\mathrm{cTfh}, \mathrm{PD}-1^{+} \mathrm{CXCR} 5^{+}\right)$in peripheral blood of $\mathrm{CR}$ were distinguishably lower than that in $\mathrm{HD}$ and the percentage of IL-21-expressing $\mathrm{CD} 4^{+} \mathrm{T}$ cells in $\mathrm{CR}$ was 
also lower than that in HD (figure 3J and K). cTfh cells could be further classified into three subsets

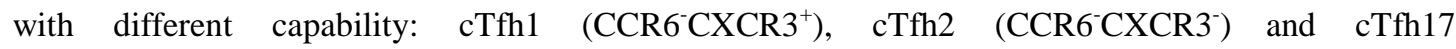
$\left(\mathrm{CCR}^{+}{ }^{+} \mathrm{CXCR} 3^{-}\right) .{ }^{16}$ As same as their parent population, all of the three subsets were reduced significantly in the $\mathrm{CR}$ compared to $\mathrm{HD}$ (figure S3A). Similar to the whole $\mathrm{CD} 4^{+} \mathrm{T}$ cells, activation indicated by ICOS and proliferation indicated by Ki-67 in Tfh cells showed no differences between CR and HD (figure S3B and C). Moreover, Th1, Th2, Th17 and Tfh in CR, consistently deviated from HD and showed no tendency to recover with the increased days post clinical discharge (figure $3 \mathrm{E}, \mathrm{H}, \mathrm{I}$ and J).

In contrast to Th effector subsets, the regulatory $\mathrm{T}$ cells $\left(\mathrm{CD} 3^{+} \mathrm{CD} 8{ }^{-} \mathrm{CD} 4^{+} \mathrm{CD} 127^{-} \mathrm{CD} 25^{+}\right.$, Treg) between CR and HD were not significantly different (figure 3L). As for Treg subsets, the frequency of activated Treg (CD45RA-FoxP3 ${ }^{\text {hi }}$, aTreg) in CR was not different from that in HD though the resting Treg (CD45RA ${ }^{+}$FoxP3 ${ }^{\text {lo }}$, rTreg) in CR showed a slight lower frequency (figure S4A). CTLA4 is one of the most important co-inhibitory molecules expressed by Tregs. As shown in Figure S4B, the frequencies of CTLA $-4^{+}$in Treg and rTreg in CR were similar as that in HD, except CTLA $-4^{+}$in aTreg of CR showed a relatively lower frequency.

Among the $\mathrm{B}$ cells, none of the frequencies of $\mathrm{B}$ cell subsets, antibody secreting cells $\left(\mathrm{CD} 27^{+} \mathrm{CD} 38^{\mathrm{hi}}, \mathrm{ASC}\right)$, naïve $\mathrm{B}$ cells $\left(\mathrm{CD} 27^{-} \mathrm{CD} 38^{\mathrm{lo}}\right)$ and memory B cells $\left(\mathrm{CD} 27^{+} \mathrm{CD} 38^{\text {lo }}, \mathrm{MBCs}\right)$, were different from that of HD (figure 4A). However, isotype-switched MBCs ( $\mathrm{IgM}^{-} \mathrm{CD} 20^{\mathrm{hi}}$ ) in CR was significantly lower than that of HD (figure 4B). More detailed analysis on B cell activation marker CD71 and co-stimulatory molecule ICOSL were carried out. Frequencies of $\mathrm{CD}^{2} 1^{+}$in both $\mathrm{IgM}^{+} \mathrm{MBCs}$ and IgM ${ }^{-}$MBCs but not naïve B cells of CR were higher than that of HD (figure 4C). Frequencies of $\mathrm{ICOSL}^{+}$in all $\mathrm{IgM}^{+} \mathrm{MBCs}$, IgM-MBCs, and naïve B cells of CR showed no significant difference with that of HD, while higher in some individuals (figure 4C). The SARS-CoV-2 infection imposed effect on isotype-switched MBCs also appeared long lasted (figure 4B), although MBCs in CR are still in the process of active proliferation.

In $\mathrm{CD} 3{ }^{-} \mathrm{HLA}-\mathrm{DR}{ }^{\mathrm{lo}}$ of $\mathrm{CR}$, the frequency of $\mathrm{Ki}-67^{+}$was significantly lower than that of $\mathrm{HD}$ (figure $5 \mathrm{~A})$. Furthermore, under polyclonal stimulation, the frequency of $\mathrm{GZMB}^{+}$and $\mathrm{IFN}^{-} \gamma^{+}$in CD3 ${ }^{-} \mathrm{HLA}-\mathrm{DR}^{\mathrm{lo}}$ of $\mathrm{CR}$ were both significant lower than those of HD (figure $5 \mathrm{~B}$ and $\mathrm{C}$ ). Among the CD3 ${ }^{-} \mathrm{HLA}-\mathrm{DR}^{\mathrm{lo}}$, the proportion of $\mathrm{IFN}^{-} \gamma^{+} \mathrm{GZMB}^{+}$cells in $\mathrm{CR}$ was remarkably reduced, while the proportion of IFN- $\gamma \mathrm{GZMB}^{+}$was markedly increased compared to those in HD (figure 5D). On the other hand, the frequency of T-bet expressing cells in CD3 HLA-DR ${ }^{\text {lo }}$ of CR was also reduced (figure 5E). Furthermore, correlation between $\mathrm{T}^{-b^{+} t^{+}}$and IFN- $\gamma^{+}$disappeared in CD3 HLA-DR ${ }^{\text {lo }}$ of CR, compared to the good correlation in that of HD. Further analysis showed that about $85 \%$ cells of the CD3 ${ }^{-} \mathrm{HLA}^{-} \mathrm{DR}^{\text {lo }}$ population were $\mathrm{CD} 56^{+} \mathrm{NK}$ cells in both $\mathrm{CR}$ and $\mathrm{HD}$ cohort (figure S5A and B), suggesting the phenotypes of CD3 HLA-DR ${ }^{\text {lo }}$ shown above were mostly ascribed to NK.

\section{Discussion}

In this study, we generated a cross sectional lymphocyte response data of a clinical recovered COVID-19 cohort in Wuhan. By using flow cytometry with different molecular marker sets, we depicted an overview picture of $\mathrm{CD} 8^{+} \mathrm{T}, \mathrm{CD} 4^{+} \mathrm{T}, \mathrm{B}$ as well as $\mathrm{CD} 3{ }^{-} \mathrm{HLA}-\mathrm{DR}{ }^{\mathrm{lo}}$ cell subsets on the aspects of differentiation, proliferation, activation and function. In CR individuals, a significant loss of $\mathrm{CD} 4^{+} \mathrm{T}$ cells still sustained long after clinical recovery from characteristic lymphopenia caused by acute SARS-CoV-2 infection. Specifically, the loss was embodied in significant degree on the decreased percentages of $\mathrm{CD} 4^{+} \mathrm{Tcm}$ in $\mathrm{CD} 4^{+} \mathrm{T}$ cell population (figure 1B) of $\mathrm{CR}$ cohort. 
What's even more remarkable is that profound lowered functions was observed in almost all $\mathrm{T}$ cell subsets we tested for the CR cohort, including Th1, Th2, Th17, Tfh, Tc1, Tc2, Tc17. The lowered functions were persistent to even 11 weeks after the $\mathrm{CR}$ cohort had clinically recovered. This suggests that the COVID-19 patients experienced long lasting repression on functions in general in both $\mathrm{CD} 4^{+}$ and $\mathrm{CD}^{+} \mathrm{T}$ cells. The long-lasting dysfunction of $\mathrm{T}$ lymphocytes is common in chronic virus infected patients such as AIDS and hepatitis $\mathrm{C}$, or cancer patients, ${ }^{17-19}$ but is rarely reported in acute virus infection, except the reported loss of Th17 in influenza infected individuals. ${ }^{20}$ To our knowledge, there is currently no report to tell whether this kind of long-lasting lowered function happens or not in the highly pathogenic corona viruses, MERS-CoV or SARS-CoV infected patients. Our findings in the present study suggested that the SARS-CoV-2 infection likely left unique imprints on lymphocytes and kept suppression on the functions of lymphocytes for a long time. The mechanism underlying the specific lymphocyte loss in COVID-19 patients warrant further investigations.

It should be noted that the frequencies of cTfhs were reduced significantly in the CR compared to HD, but the expression levels of both Ki-67 and ICOS in cTfh between CR and HD were similar, suggesting no suppression on the proliferation and activation of cTfh of CR (figure 3J and S3). This non-suppression is in line with the elevated activation indicated by CD71 and ICOSL in memory B cells of $\mathrm{CR}^{21}{ }^{21}$ The lower frequency of IgM- isotype-switched MBC in $\mathrm{CR}$ than in $\mathrm{HD}$, indicated the induction of isotype-switched MBC might be repressed by SARS-CoV-2 infection. This repression of isotype-switch might be related with the reduced frequency of $\mathrm{cTfh}$, which are critical for the differentiation and isotype-switch of germ center B cells. ${ }^{21}$ In recent report on the antibody response of SARS-CoV-2 recovered individuals, the SARS-CoV-2 specific antibody responses sharply waned within 8 weeks. ${ }^{22}$ As the $\mathrm{IgM}^{-}$switched MBC are more responsive than $\operatorname{IgM}^{+} \mathrm{MBC},{ }^{23}$ the decrease of isotype-switched MBC might be one reason for explaining the sharp waning of SARS-CoV-2 specific antibody responses.

We further found that the proportions of IFN- $\gamma^{-} \mathrm{GZMB}^{+}$cells were significantly higher in $\mathrm{CD} 4^{+} \mathrm{T}$ cells, $\mathrm{CD}^{+} \mathrm{T}$ cells as well as in CD3 HLA-DR ${ }^{\text {lo }}$ lymphocytes of CR cohort compared to HD in contrary to the lower proportions of IFN $-\gamma^{+}$cells in the corresponding cell populations (figure 1D, 2D and 5E). In the CD3-HLA-DR ${ }^{\text {lo }}$ population, the correlation between T-bet and IFN- $\gamma$ disappeared in CR cohort compared to the nice correlation in HD cohort (figure 5H). These data suggested perturbation also existed in $\mathrm{T}$ cells and CD3 HLA-DR ${ }^{\text {lo }}$ lymphocytes of COVID-19 CR individuals besides repression. However, further classification on the CD3 ${ }^{-} \mathrm{HLA}^{-\mathrm{DR}^{\mathrm{lo}}}$ lymphocytes was missed in this study due to lack of corresponding antibodies during the COVID-19 crisis in Wuhan. Although about $85 \%$ of the CD3 HLA-DR ${ }^{\mathrm{lo}}$ lymphocytes might be NK as we assayed further in either CR or HD cohort, there is another important cell population, innate lymphocytes (ILCs), also located in CD3 HLA-DR ${ }^{\text {lo }}$. The responses and status of the NKs and ILCs in CR should be of high interest for understanding COVID-19.

In summary, we provided a cross sectional profile of lymphocyte responses of a clinical recovered COVID-19 cohort and found long-term significant phenotype alterations and potential dysfunctions of lymphocytes in the cohort clinically recovered from laboratory-confirmed COVID-19. We still do not know how long the phenotype alterations and potential dysfunctions of lymphocytes will last. As reported, $\mathrm{CD} 4^{+} \mathrm{T}$ cells and $\mathrm{CD} 8^{+} \mathrm{T}$ cells and $\mathrm{NK}$ cells are all critical for the control of intracellular pathogen infections and tumors ${ }^{17,24,25}$ and could coordinate with each other. ${ }^{26,27} \mathrm{CD} 4^{+} \mathrm{T}$ cells, especially the Tfh, and B cells are also critical for the processes that lead to long-term humoral immunity ${ }^{16}$. The broad and long-term dysfunction of these lymphocytes subsets might profoundly impair the immune 
medRxiv preprint doi: https://doi.org/10.1101/2020.07.01.20144030; this version posted July 2,2020 . The copyright holder for this preprint (which was not certified by peer review) is the author/funder, who has granted medRxiv a license to display the preprint in perpetuity.

All rights reserved. No reuse allowed without permission.

surveillance and protection executed by lymphocytes in the COVID-19 clinical recovered individuals, though broad and strong SARS-CoV-2 specific memory $\mathrm{CD}^{+} \mathrm{T}$ cells and $\mathrm{CD} 8^{+} \mathrm{T}$ cells could be detected in COVID-19 patients. ${ }^{28,29}$ A recent study on the SARS-CoV-2-specific humoral and cellular immunity in COVID-19 convalescent individuals highlighted that anti-viral $\mathrm{T}$ cells may not be maintained at high numbers in the PBMCs in the recovered patients. ${ }^{30}$ This alerts us more concerns on the prognosis of COVID-19 patients. Considering that SARS-CoV-2 specific antibody response also sharply waned, ${ }^{22}$ it is hard to speculate whether the SARS-CoV-2 clinical recovered population could resist re-infection for a long period. If the dysfunction of lymphocytes sustained long time, this population might be even more susceptible to SARS-CoV-2 infection or other viral infections. Hence, more comprehensive profile studies on the relationship of immune responses and SARS-CoV-2 infection longitudinally and cross-sectionally in different cohorts are urgently needed.

\section{Contributors}

JY, MZ, EZ contributed to the conception, design, data acquisition, analysis, and interpretation, and drafted and critically revised the manuscript. $\mathrm{KH}$ contributed to the data acquisition, clinical descriptions and critically revised the manuscript. QY, DZ, JiaX, YC, MS, BZ, JieX, YL, YH contributed to the data acquisition and analysis. XZ, CH and YS made contribution to the study concept, design and critically revised the manuscript. HY contributed to the conception, design, data analysis, and interpretation, and drafted and critically revised the manuscript. All of the authors gave final approval and agreed to be accountable for all aspects of the work.

\section{Declaration of interests}

We declare no competing interests.

\section{Acknowledgments}

We thank the COVID-19 recovered individuals and healthy donors involved in this study and staff at Wuhan Jinyintan Hospital. 
medRxiv preprint doi: https://doi.org/10.1101/2020.07.01.20144030; this version posted July $2,2020$. The copyright holder for this preprint (which was not certified by peer review) is the author/funder, who has granted medRxiv a license to display the preprint in perpetuity.

All rights reserved. No reuse allowed without permission.

\section{References}

1. Leslie M. T cells found in coronavirus patients 'bode well' for long-term immunity. Science 2020; 368(6493): 809-10.

2. Callaway E. Coronavirus vaccines: five key questions as trials begin. Nature 2020; 579(7800): 481.

3. Corey L, Mascola JR, Fauci AS, Collins FS. A strategic approach to COVID-19 vaccine R\&D. Science 2020; 368(6494): 948-50.

4. Huang C, Wang Y, Li X, et al. Clinical features of patients infected with 2019 novel coronavirus in Wuhan, China. Lancet 2020; 395(10223): 497-506.

5. Grifoni A, Weiskopf D, Ramirez SI, et al. Targets of $\mathrm{T}$ Cell Responses to SARS-CoV-2 Coronavirus in Humans with COVID-19 Disease and Unexposed Individuals. Cell 2020.

6. Chen $\mathrm{G}, \mathrm{Wu} \mathrm{D}$, Guo $\mathrm{W}$, et al. Clinical and immunological features of severe and moderate coronavirus disease 2019. J Clin Invest 2020; 130(5): 2620-9.

7. Zheng M, Gao Y, Wang G, et al. Functional exhaustion of antiviral lymphocytes in COVID-19 patients. Cell Mol Immunol 2020; 17(5): 533-5.

8. Mazzoni A, Salvati L, Maggi L, et al. Impaired immune cell cytotoxicity in severe COVID-19 is IL-6 dependent. J Clin Invest 2020.

9. Wilk AJ, Rustagi A, Zhao NQ, et al. A single-cell atlas of the peripheral immune response in patients with severe COVID-19. Nat Med 2020.

10. Zhang X, Tan Y, Ling Y, et al. Viral and host factors related to the clinical outcome of COVID-19. Nature 2020.

11. Giamarellos-Bourboulis EJ, Netea MG, Rovina N, et al. Complex Immune Dysregulation in COVID-19 Patients with Severe Respiratory Failure. Cell Host Microbe 2020; 27(6): 992-1000 e3.

12. Ouyang Y, Yin J, Wang W, et al. Down-regulated gene expression spectrum and immune responses changed during the disease progression in COVID-19 patients. Clin Infect Dis 2020.

13. Jingyi Yang EZ, Maohua Zhong, Qingyu Yang, Ke Hong, Ting Shu, Dihan Zhou, Jie Xiang, Jianbo Xia, Xi Zhou, Dingyu Zhang, Chaolin Huang, You Shang, Huimin Yan. Impaired T cell functions along with elevated activated Tregs at the early stage of asymptomatic SARS-CoV-2 infection. medRxiv 2020; 20108852.

14. Cao B, Wang Y, Wen D, et al. A Trial of Lopinavir-Ritonavir in Adults Hospitalized with Severe Covid-19. The New England journal of medicine 2020.

15. Crotty S. T Follicular Helper Cell Biology: A Decade of Discovery and Diseases. Immunity 2019; 50(5): 1132-48.

16. Morita R, Schmitt N, Bentebibel SE, et al. Human blood CXCR5(+)CD4(+) T cells are counterparts of $\mathrm{T}$ follicular cells and contain specific subsets that differentially support antibody secretion. Immunity 2011; 34(1): 108-21.

17. Douek DC, Brenchley JM, Betts MR, et al. HIV preferentially infects HIV-specific CD4+ T cells. Nature 2002; 417(6884): 95-8.

18. Ahmed F, Ibrahim A, Cooper CL, Kumar A, Crawley AM. Chronic Hepatitis C Virus Infection Impairs M1 Macrophage Differentiation and Contributes to CD8(+) T-Cell Dysfunction. Cells 2019; 8(4).

19. Hodgins JJ, Khan ST, Park MM, Auer RC, Ardolino M. Killers 2.0: NK cell therapies at the forefront of cancer control. J Clin Invest 2019; 129(9): 3499-510.

20. Jiang TJ, Zhang JY, Li WG, et al. Preferential loss of Th17 cells is associated with CD4 T cell 
medRxiv preprint doi: https://doi.org/10.1101/2020.07.01.20144030; this version posted July $2,2020$. The copyright holder for this preprint (which was not certified by peer review) is the author/funder, who has granted medRxiv a license to display the preprint in perpetuity.

All rights reserved. No reuse allowed without permission.

1

activation in patients with 2009 pandemic H1N1 swine-origin influenza A infection. Clin Immunol 2010; 137(3): 303-10.

21. Weinstein JS, Laidlaw BJ, Lu Y, et al. STAT4 and T-bet control follicular helper T cell development in viral infections. J Exp Med 2018; 215(1): 337-55.

22. Long QX, Tang XJ, Shi QL, et al. Clinical and immunological assessment of asymptomatic SARS-CoV-2 infections. Nat Med 2020.

23. Marasco E, Farroni C, Cascioli S, et al. B-cell activation with CD40L or CpG measures the function of B-cell subsets and identifies specific defects in immunodeficient patients. Eur J Immunol 2017; 47(1): 131-43.

24. Molgora M, Bonavita E, Ponzetta A, et al. IL-1R8 is a checkpoint in NK cells regulating anti-tumour and anti-viral activity. Nature 2017; 551(7678): 110-4.

25. Yang W, Bai Y, Xiong Y, et al. Potentiating the antitumour response of CD8(+) T cells by modulating cholesterol metabolism. Nature 2016; 531(7596): 651-5.

26. Bai L, Peng H, Hao X, et al. CD8(+) T Cells Promote Maturation of Liver-Resident NK Cells Through the CD70-CD27 axis. Hepatology 2019; 70(5): 1804-15.

27. Kelly MN, Zheng M, Ruan S, Kolls J, D'Souza A, Shellito JE. Memory CD4+ T cells are required for optimal NK cell effector functions against the opportunistic fungal pathogen Pneumocystis murina. J Immunol 2013; 190(1): 285-95.

28. Peng Y, Mentzer AJ, Liu G, et al. Broad and strong memory CD4 (+) and CD8 (+) T cells induced by SARS-CoV-2 in UK convalescent COVID-19 patients. bioRxiv 2020.

29. Weiskopf D, Schmitz KS, Raadsen MP, et al. Phenotype and kinetics of SARS-CoV-2-specific T cells in COVID-19 patients with acute respiratory distress syndrome. Sci Immunol 2020; 5(48).

30. Ni L, Ye F, Cheng ML, et al. Detection of SARS-CoV-2-Specific Humoral and Cellular Immunity in COVID-19 Convalescent Individuals. Immunity 2020; 52(6): 971-7 e3. 


\section{Figure Legends}

Figure 1. $\mathrm{CD8}^{+} \mathrm{T}$ cells, $\mathrm{CD4}^{+} \mathrm{T}$ cells, $\mathrm{B}$ cells and $\mathrm{CD3} \mathrm{HLA}^{-D R^{\mathrm{lo}}}$ lymphocytes in peripheral blood of healthy donor cohort (HD) and clinical recovered cohort (CR). A, Gating strategies of $\mathrm{CD}^{+} \mathrm{T}$ cells $\left(\mathrm{CD}^{+}{ }^{+} \mathrm{CD} 4^{-} \mathrm{CD} 8^{+}\right), \mathrm{CD}^{+}{ }^{+} \mathrm{T}$ cells $\left(\mathrm{CD}^{+} \mathrm{CD}^{-} \mathrm{CD} 4^{+}\right)$, B cells $\left(\mathrm{CD} 3 \mathrm{CD}^{-} 9^{+} \mathrm{HLA}^{-\mathrm{DR}}{ }^{+}\right)$and CD3-HLA-DR ${ }^{\text {lo }}$ lymphocytes (CD3 ${ }^{-H L A-D R}{ }^{\text {lo }}$ ) in PBMCs. B, Frequencies of $\mathrm{CD}^{+} \mathrm{T}$ cells, $\mathrm{CD}^{+} \mathrm{T}$ cells, B cells and CD3-HLA-DR ${ }^{\text {lo }}$ lymphocytes in lymphocytes of HD and CR. ns, non-significant; *, $\mathrm{P}<0.05$.

Figure 2. Differentiation, activation, proliferation and function of $\mathrm{CD8}^{+} \mathrm{T}$ cells in peripheral blood of HD and CR. A, Gating strategy and the frequencies of effector $\mathrm{T}$ cells (Teff, $\mathrm{CD}^{2} 5 \mathrm{RO}^{-} \mathrm{CD}^{-} 7^{-}$), effector memory $\mathrm{T}$ cell $\left(\mathrm{Tem}, \mathrm{CD}^{2} 5 \mathrm{RO}^{+} \mathrm{CD} 27^{-}\right)$, central memory $\mathrm{T}$ cell $(\mathrm{Tcm}$, $\left.\mathrm{CD} 45 \mathrm{RO}^{+} \mathrm{CD} 27^{+}\right)$and naïve $\mathrm{T}$ cell $\left(\mathrm{CD} 45 \mathrm{RO}^{-} \mathrm{CD} 27^{+}\right.$, Tna) subsets in $\mathrm{CD} 8^{+} \mathrm{T}$ cells of PBMC. B and $\mathrm{C}$, Frequencies of HLA-DR ${ }^{+}, \mathrm{PD}-1^{+}$and $\mathrm{Ki}-67^{+}$in $\mathrm{CD} 8^{+} \mathrm{T}$ cells. To analyze the function of $\mathrm{CD} 8^{+} \mathrm{T}$ cells, PBMCs were stimulated by PMA/Ionomycin for $4.5 \mathrm{~h}$ in the presence of BFA and monensin. The production of IL-2, Granzyme B (GZMB, D), IFN- $\gamma$ (E), IFN- $\gamma /$ IL-2, IFN- $\gamma /$ GZMB co-expression (G), IL-4 (H) and IL-17A (I) by CD8 ${ }^{+}$T cells were analyzed by intracellular staining. F, T-bet ${ }^{+}$cells in $\mathrm{CD} 8^{+}$ $\mathrm{T}$ cells without stimulation (left panel), and correlation of T-bet ${ }^{+}$with $\mathrm{IFN}^{-} \gamma^{+}$(right panel). The correlation of days post discharge in CR with frequency of IFN- $\gamma^{+}(\mathrm{E}), \mathrm{IL}-4^{+}(\mathrm{H})$ and IL-17A $\mathrm{A}^{+}$(I) in $\mathrm{CD}^{+} \mathrm{T}$ cells were displayed in the right panels. ns, non-significant; *, $\mathrm{P}<0.05 ; * *, \mathrm{P}<0.01$; ***, $\mathrm{P}<0.001 ; * * * *, \mathrm{P}<0.0001$.

Figure 3. Differentiation, activation, proliferation and function of $\mathrm{CD}^{+} \mathrm{T}$ cells in peripheral blood of $\mathrm{HD}$ and CR. A, Frequencies of effector T cells (Teff, $\mathrm{CD}^{2} 5 \mathrm{RO}^{-} \mathrm{CD}^{-} 7^{\circ}$ ), effector memory $\mathrm{T}$

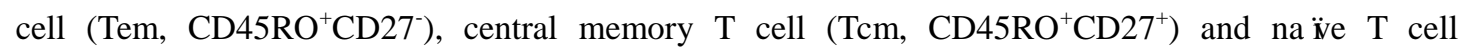
(CD45ROCD27 $7^{+}$, Tna) subsets in $\mathrm{CD}^{+}{ }^{+} \mathrm{T}$ cells of PBMC. B and C, Frequencies of HLA-DR ${ }^{+}$, PD- ${ }^{+}$ (B) and $\mathrm{Ki}-67^{+}(\mathrm{C})$ in $\mathrm{CD} 4^{+} \mathrm{T}$ cells. To analyze the function of $\mathrm{CD} 4^{+} \mathrm{T}$ cells, PBMCs were stimulated by PMA/Ionomycin for $4.5 \mathrm{~h}$ in the presence of BFA and monensin. The production of IL-2, GZMB (D), IFN- $\gamma$ (E left panel), IFN- $\gamma /$ IL-2, IFN- $\gamma /$ GZMB co-expression (G), IL-4 (H), IL-17A (I) and IL-21 (K) by $\mathrm{CD}^{+} \mathrm{T}$ cells of $\mathrm{HD}$ and $\mathrm{CR}$ were analyzed by intracellular staining. F, T-bet ${ }^{+}$cells in $\mathrm{CD} 4^{+} \mathrm{T}$ cells without stimulation (left panel), and correlation of T-bet ${ }^{+}$with IFN- $\gamma^{+}$(right panel). J and L, Gating strategy and the frequency of circulating follicular helper T cells $\left(\mathrm{cTfh}, \mathrm{CXCR} 5^{+} \mathrm{PD}-1^{+}\right.$) and Tregs $\left(\mathrm{CD} 25^{+} \mathrm{CD} 127^{+}\right)$in $\mathrm{CD}^{+} \mathrm{T}$ cells of $\mathrm{HD}$ and $\mathrm{CR}$. The correlation of days post discharge in $\mathrm{CR}$ with frequency of IFN- $\gamma^{+}(\mathrm{E}), \mathrm{IL}_{-} 4^{+}(\mathrm{H}), \mathrm{IL}^{-17 \mathrm{~A}^{+}}(\mathrm{I})$ and $\mathrm{cTfh}(\mathrm{J})$ in $\mathrm{CD} 4^{+} \mathrm{T}$ cells were displayed in the right panels. ns, non-significant; *, $\mathrm{P}<0.05 ; * *, \mathrm{P}<0.01 ; * * * *, \mathrm{P}<0.0001$.

Figure 4. Differentiation and activation of $B$ cells in peripheral blood of $H D$ and $C R$. A, Gating strategy and the frequencies of naïve $\mathrm{B}$ cells $\left(\mathrm{CD} 38^{\mathrm{lo}} \mathrm{CD} 27^{\circ}\right)$, antigen secreting cell (ASC, $\mathrm{CD} 38^{\mathrm{hi}} \mathrm{CD} 27^{-}$) and memory B cells (MBCs, $\mathrm{CD} 38^{\mathrm{lo}} \mathrm{CD} 27^{+}$) subsets in $\mathrm{B}$ cells. B, The frequencies of non- isotype-switched $\operatorname{IgM}^{+} \mathrm{MBCs}\left(\operatorname{IgM}^{+} \mathrm{CD} 20^{\text {hi }}\right)$ and isotype-switched $\operatorname{IgM}^{-} \mathrm{MBC}$ (IgM-CD20 ${ }^{\text {hi }}$ ) subsets in B cells. C, The frequencies of $\mathrm{CD}^{+} 1^{+}$and $\mathrm{ICOS}^{+}$in $\mathrm{IgM}^{+} \mathrm{MBCs}$, $\mathrm{IgM}^{-} \mathrm{MBC}$ and naïve $\mathrm{B}$ cells. ns, non-significant; *, $\mathrm{P}<0.05$.

Figure 5. Proliferation and function of CD3 HLADR ${ }^{10}$ lymphocytes cells in peripheral blood of HD and CR. A, Frequency of Ki- $67^{+}$cells in CD3 HLADR ${ }^{\text {lo }}$ lymphocytes in PBMCs. To analyze the function of CD3 ${ }^{-} \mathrm{HLADR}^{\mathrm{lo}}$ lymphocytes, PBMCs were stimulated by PMA/Ionomycin for $4.5 \mathrm{~h}$ in the presence of BFA and monensin. The production of GZMB (B), IFN- $\gamma$ (left panel of C) and 
medRxiv preprint doi: https://doi.org/10.1101/2020.07.01.20144030; this version posted July 2,2020 . The copyright holder for this preprint (which was not certified by peer review) is the author/funder, who has granted medRxiv a license to display the preprint in perpetuity.

All rights reserved. No reuse allowed without permission.

1 IFN- $\gamma /$ GZMB co-expression (D) by CD3 ${ }^{-} \mathrm{HLADR}^{\mathrm{lo}}$ lymphocytes were analyzed by intracellular 2 staining. E, T-bet ${ }^{+}$cells in $\mathrm{CD}^{-} \mathrm{HLADR}^{\text {lo }}$ lymphocytes without stimulation (left panel) and correlation 3 of T-bet $^{+}$with IFN- $\gamma^{+}$(right panel) in $\mathrm{CD}^{-} \mathrm{HLADR}^{\mathrm{lo}}$ lymphocytes. Correlation of days post discharge 4 in $\mathrm{CR}$ with frequency of IFN- $\gamma^{+}$in $\mathrm{CD}^{-} \mathrm{HLADR}^{\mathrm{lo}}$ lymphocytes were displayed in the right panel of $\mathrm{C}$. $5 \quad *, \mathrm{P}<0.05 ; * *, \mathrm{P}<0.01 ; * * *, \mathrm{P}<0.001 ; * * * *, \mathrm{P}<0.0001$. 


\section{Figure 1}
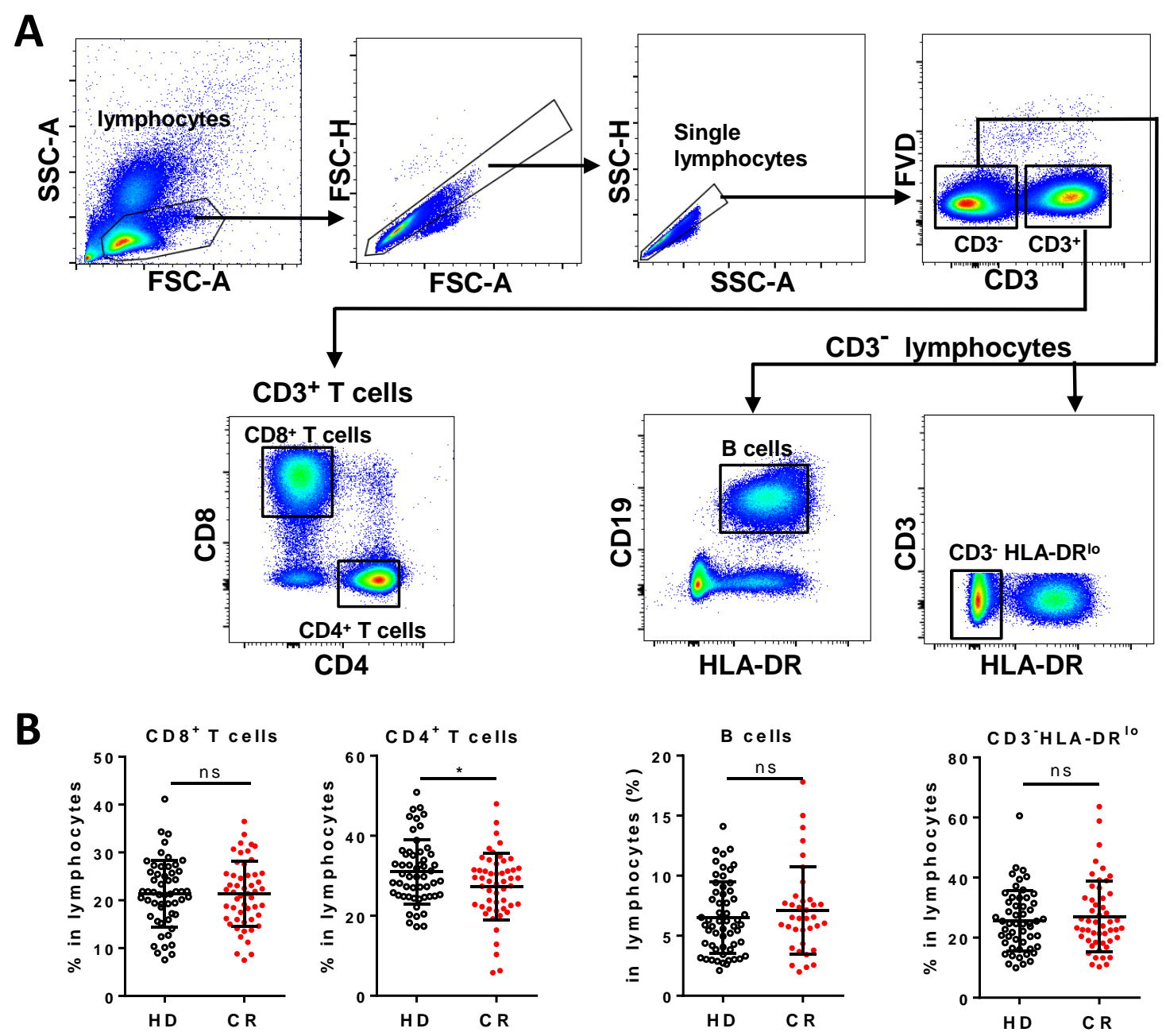
A



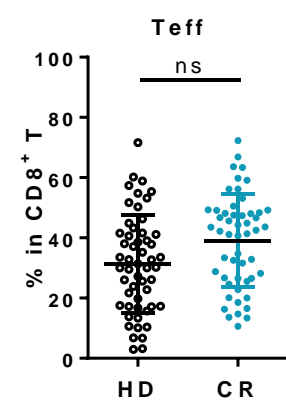
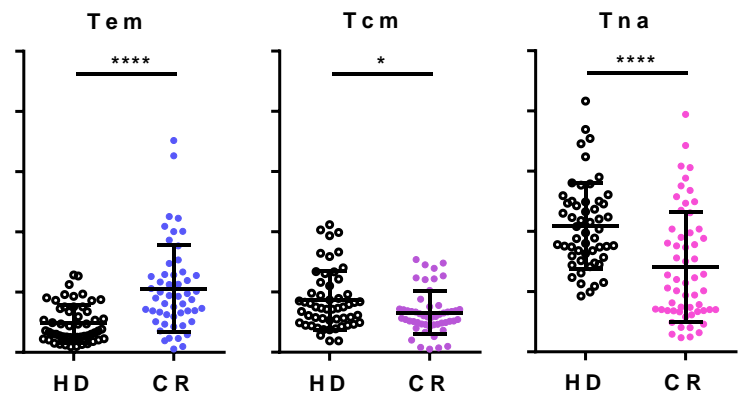

C

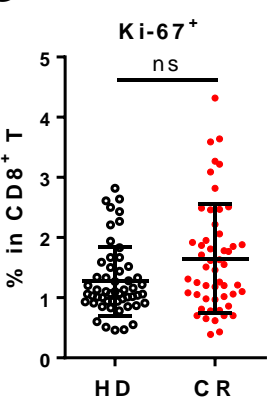

D
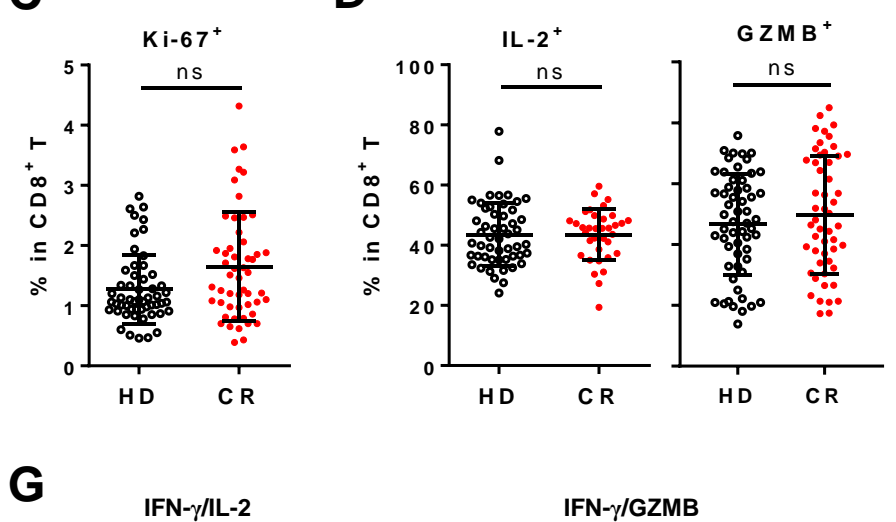

IFN- $\gamma /$ GZMB
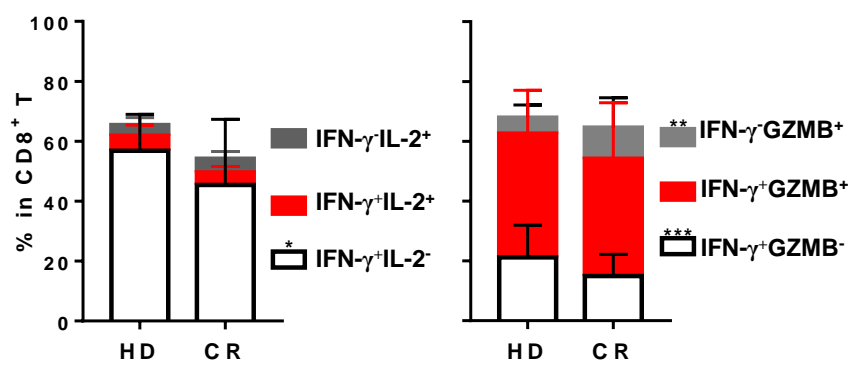

E

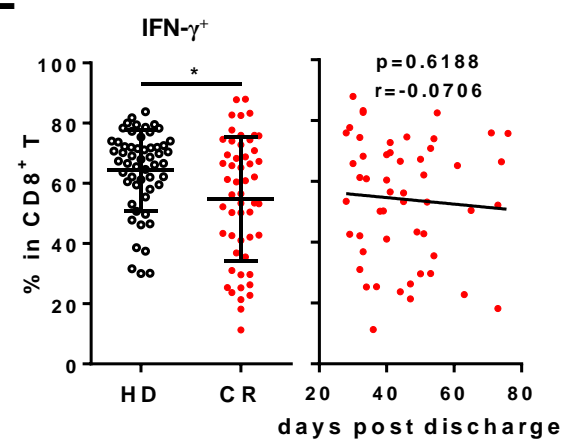

H

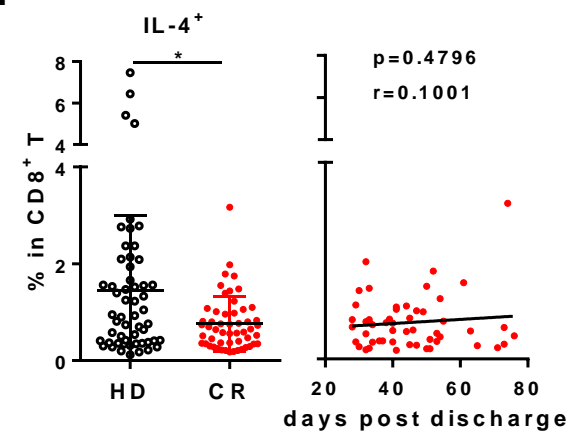

B

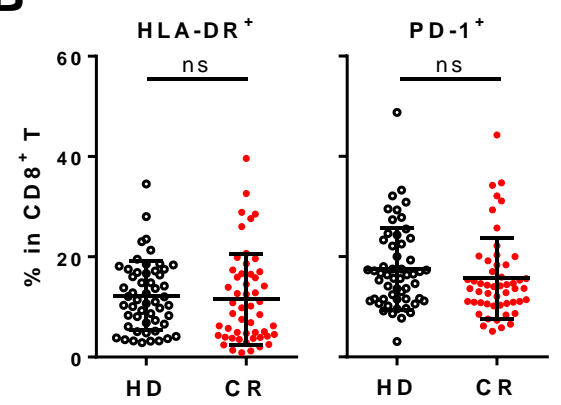

F

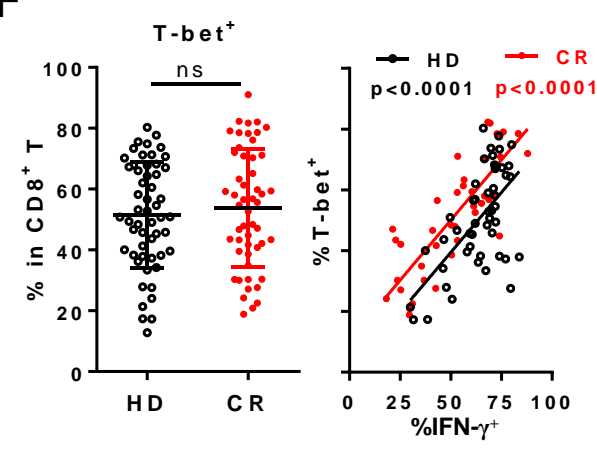

I

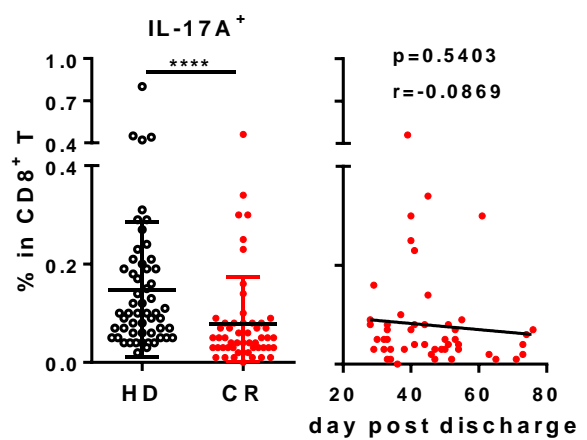



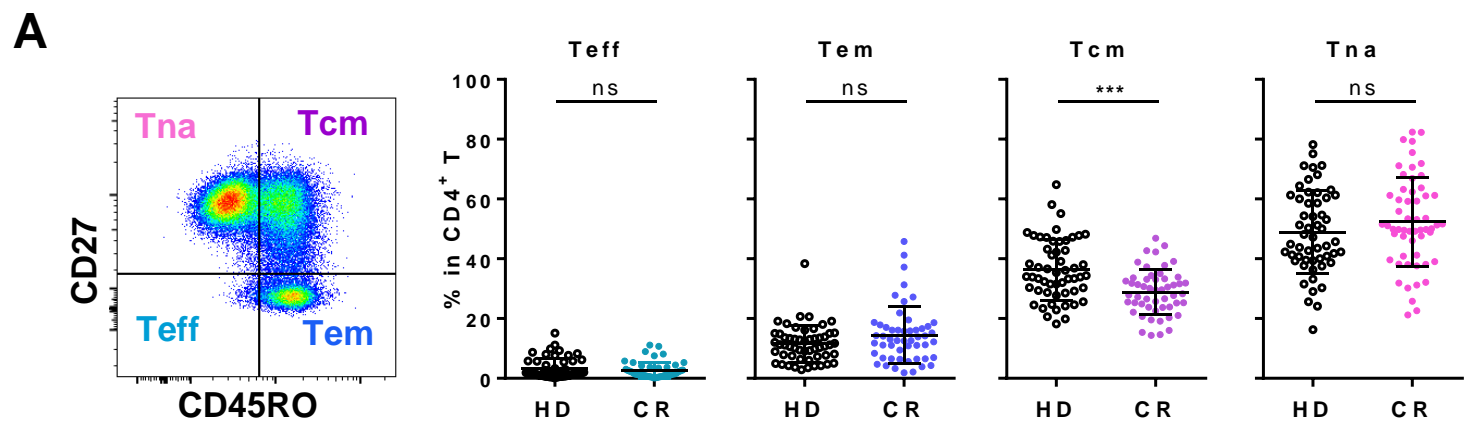

C

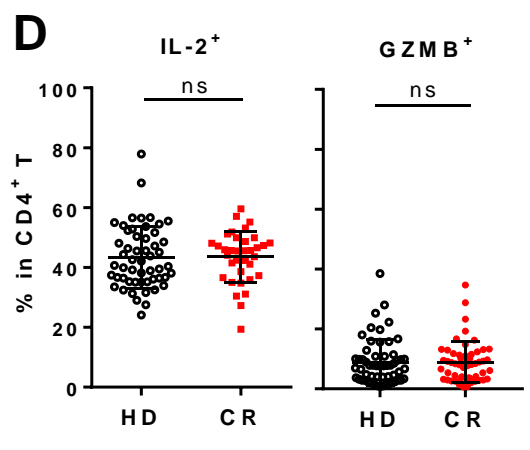

\section{E IFN- $\gamma^{+}$}
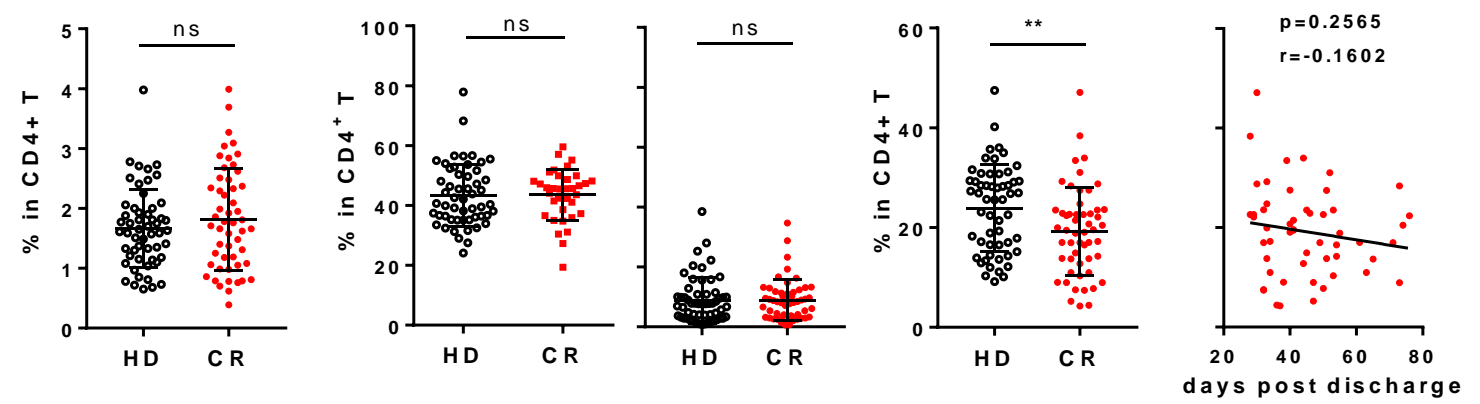

G IFN- $\gamma / \mathrm{IL}-2$

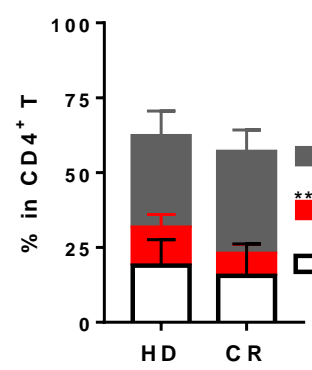

J

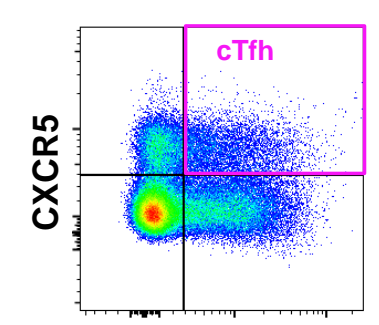

PD-1
IFN- $\gamma /$ GZMB

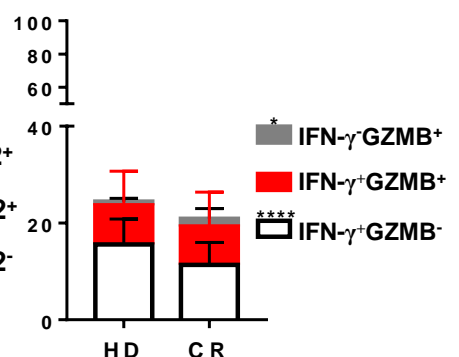

cTfh

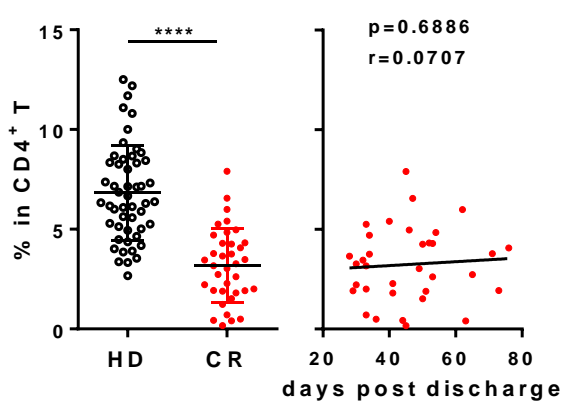

\section{H}

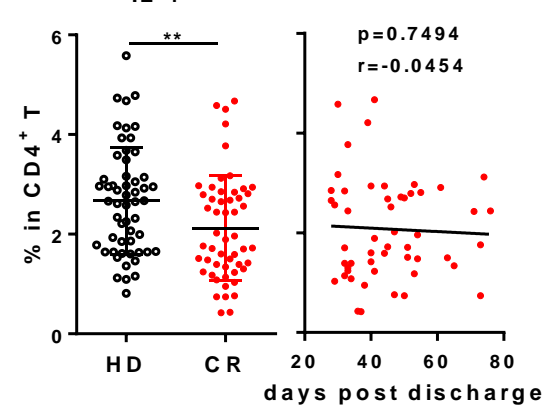

B

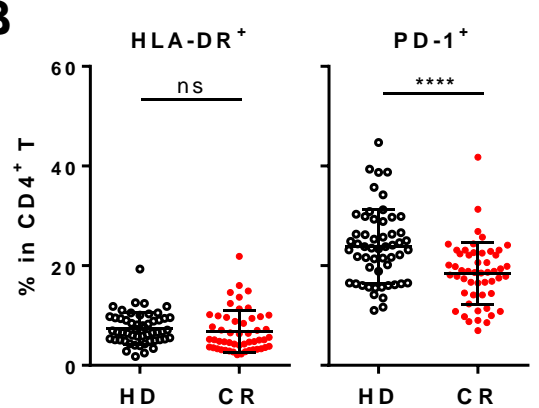

F
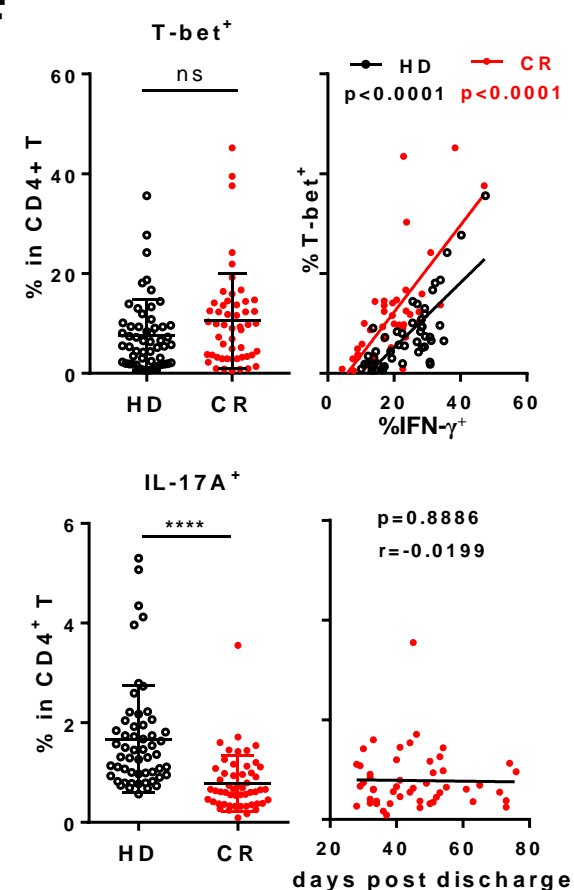



L

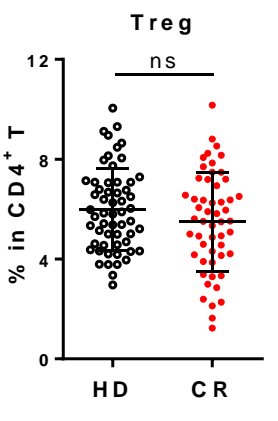




\section{Figure 4}
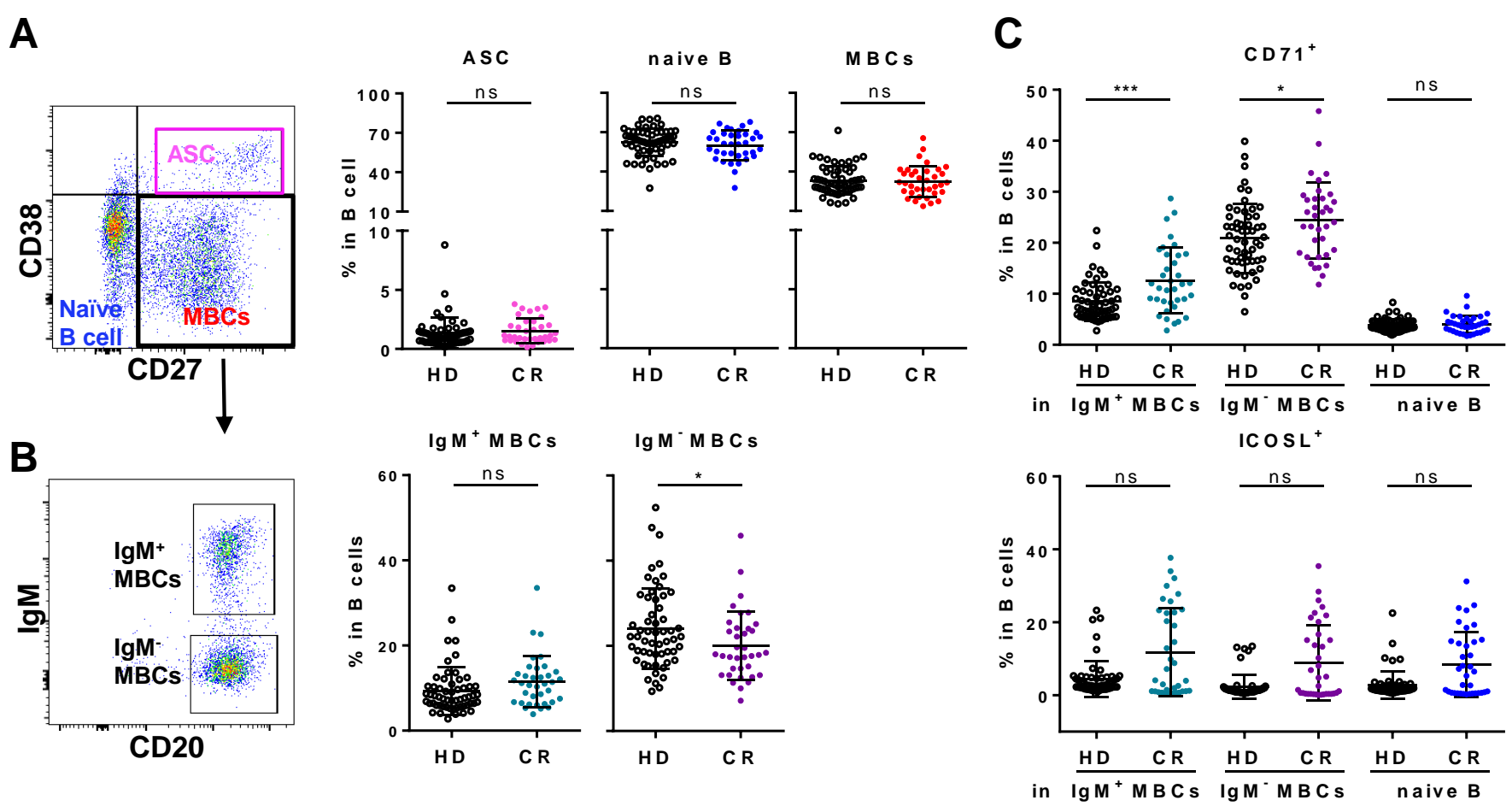
Figure 5
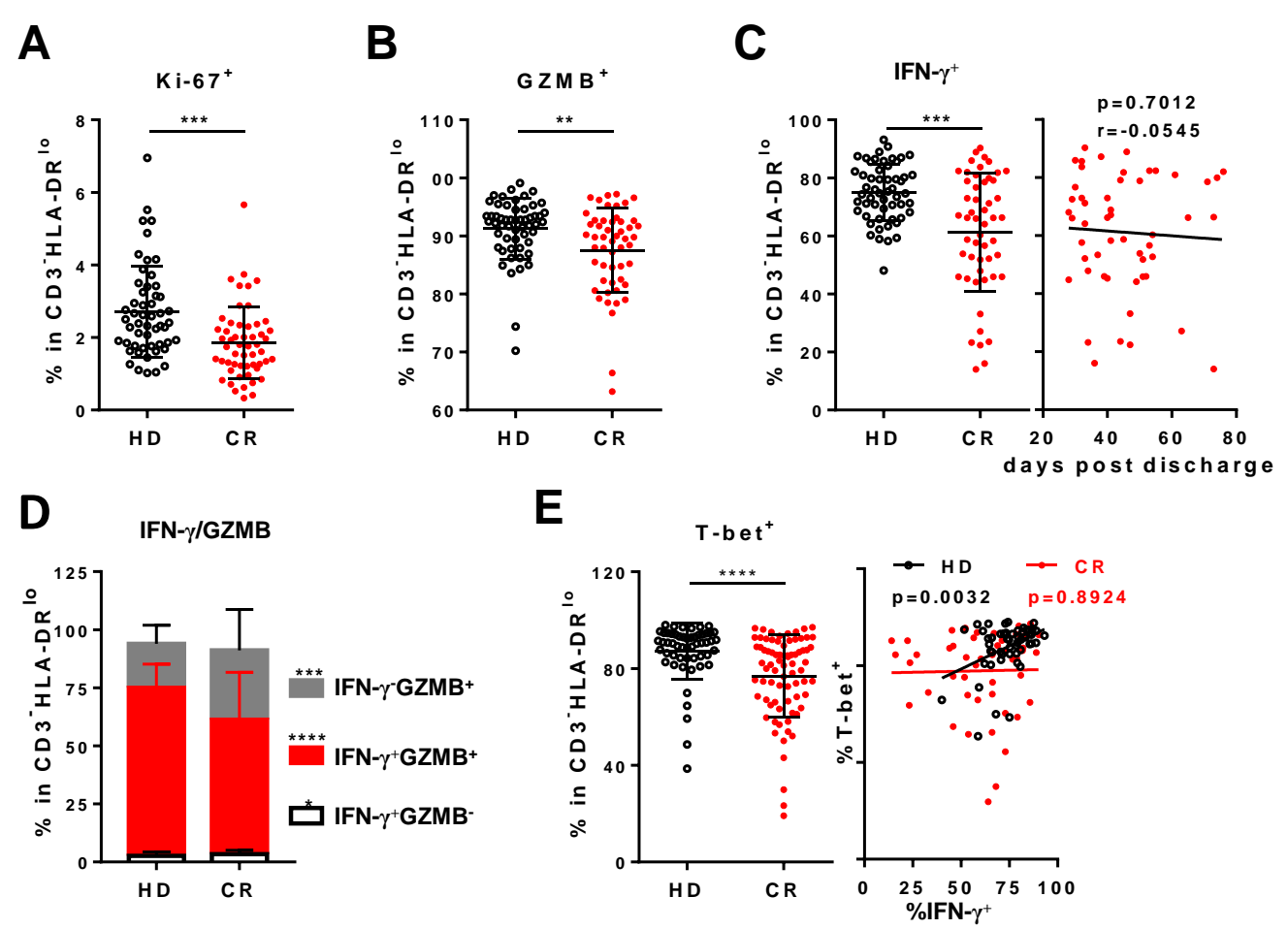


\section{Supplementary figures}

A


B
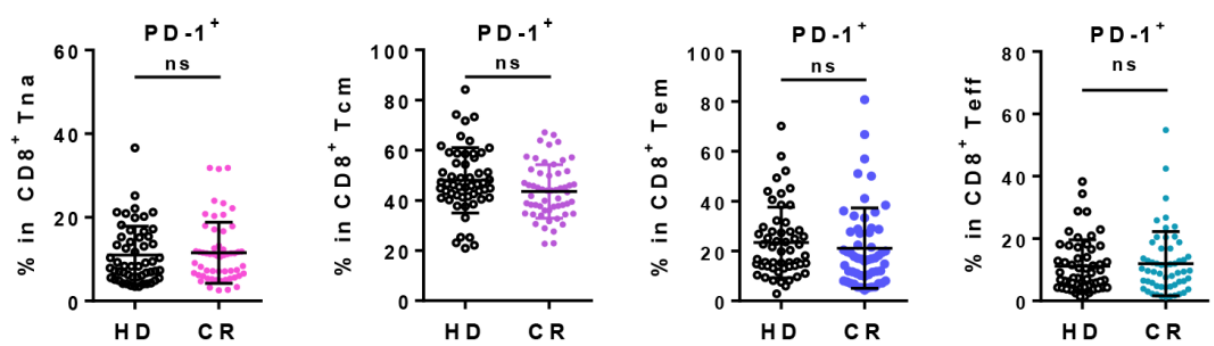

C
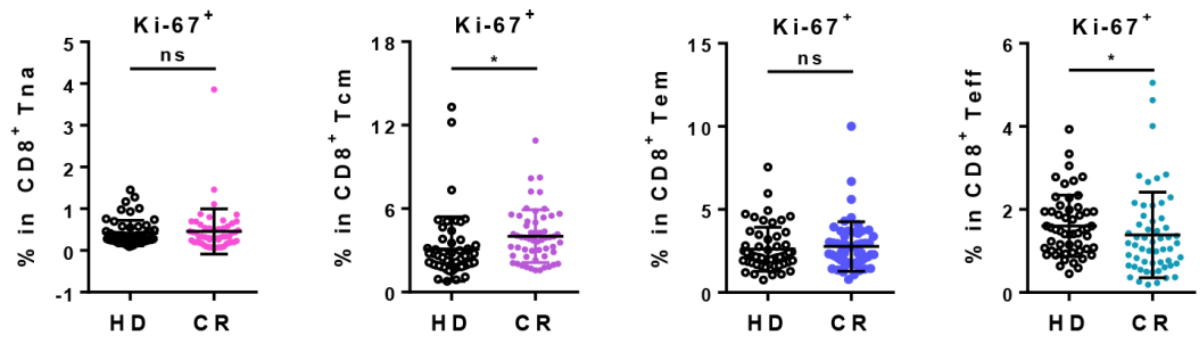

Figure S1 Activation and proliferation of the Tna, Tcm, Tem and Teff subsets of $\mathrm{CDB}^{+} \mathrm{T}$

cells. Frequencies of $\mathrm{HLA}-\mathrm{DR}^{+}(\mathrm{A}), \mathrm{PD}-1^{+}(\mathrm{B})$ and $\mathrm{Ki}-67^{+}(\mathrm{C})$ in naïve T cells (Tna), central memory $\mathrm{T}$ cells $(\mathrm{Tcm})$, effector memory $\mathrm{T}$ cell $(\mathrm{Tem})$ and effector $\mathrm{T}$ cell (Teff) subsets of $\mathrm{CD}^{+} \mathrm{T}$ cells in PBMCs of healthy donors $(\mathrm{n}=55)$ and clinically recovered COVID-19 individuals (CR). ns, non-significant; *, $\mathrm{P}<0.05$. 
A
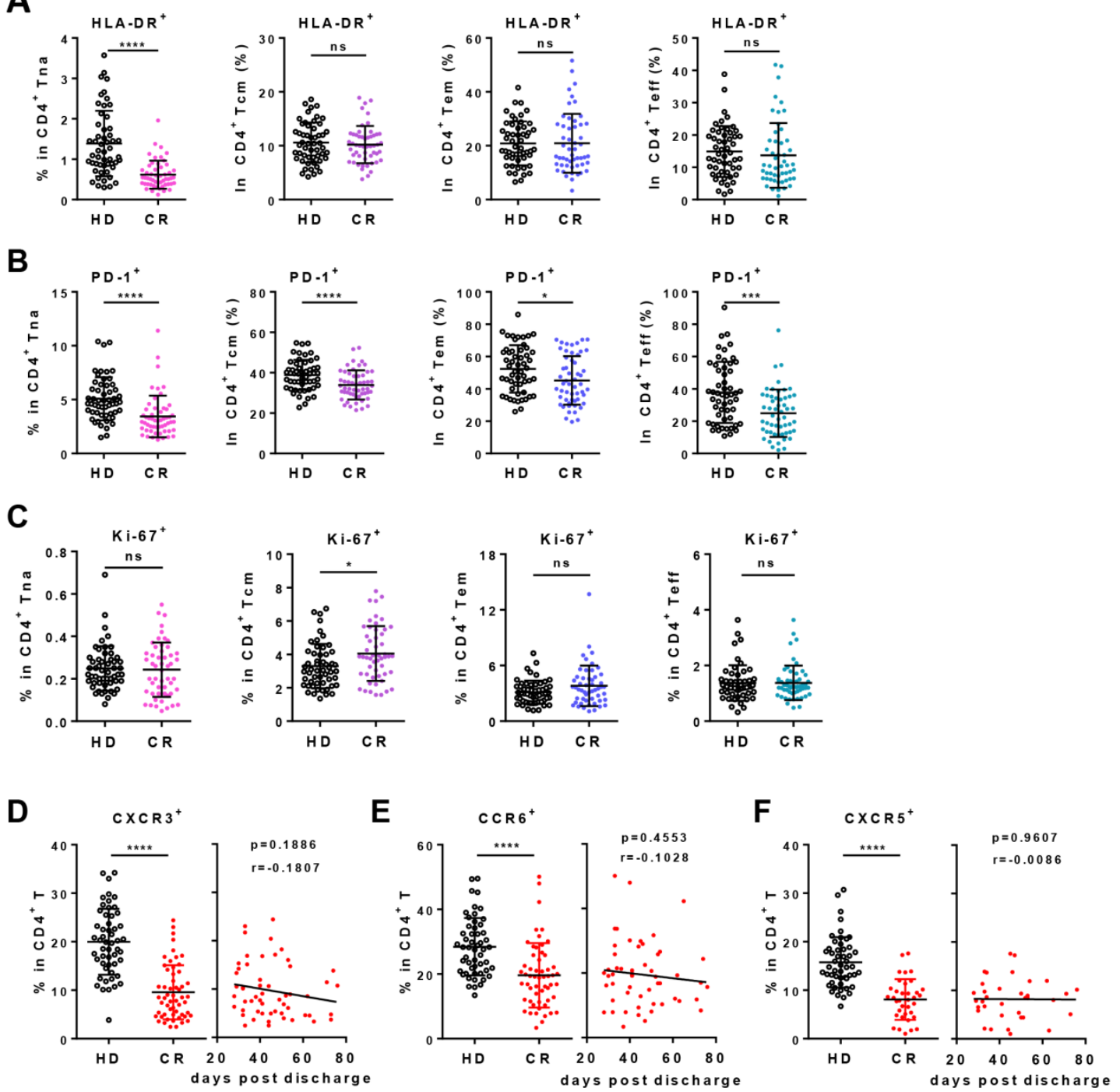

Figure S2 Activation and proliferation of the Tna, Tcm, Tem and Teff subsets of $\mathrm{CD4}^{+} \mathrm{T}$ cells and chemokine receptor expression in $\mathbf{C D 4}^{+} \mathbf{T}$ cells. Frequencies of $\operatorname{HLA}_{-1 R^{+}}(\mathrm{A}), \mathrm{PD}-1^{+}$ (B) and Ki-67 ${ }^{+}(\mathrm{C})$ in naïve T cells (Tna), central memory $\mathrm{T}$ cells $(\mathrm{Tcm})$, effector memory $\mathrm{T}$ cell (Tem) and effector $\mathrm{T}$ cell (Teff) subsets of $\mathrm{CD} 4^{+} \mathrm{T}$ cells in PBMCs of healthy donors $(\mathrm{n}=55)$ and clinically recovered COVID-19 individuals (CR). D-F, Frequencies of CXCR3 ${ }^{+}(\mathrm{D})$, $\mathrm{CCR}^{+}(\mathrm{E})$ and $\mathrm{CXCR}^{+}(\mathrm{F})$ in $\mathrm{CD}^{+}{ }^{+} \mathrm{T}$ cells were shown in the left panel of C-E. The correlation of days post discharge with frequency of $\mathrm{CXCR}^{+}(\mathrm{D}), \mathrm{CCR}^{+}(\mathrm{E})$ and $\mathrm{CXCR}^{+}(\mathrm{F})$ in $\mathrm{CD}^{+} \mathrm{T}$ cells of $\mathrm{CR}$ were displayed in the right panel of $\mathrm{C}$-E. ns, non-significant; *, $\mathrm{P}<0.05$; ***, $\mathrm{p}<0.001 ; * * * *, \mathrm{p}<0.0001$ 

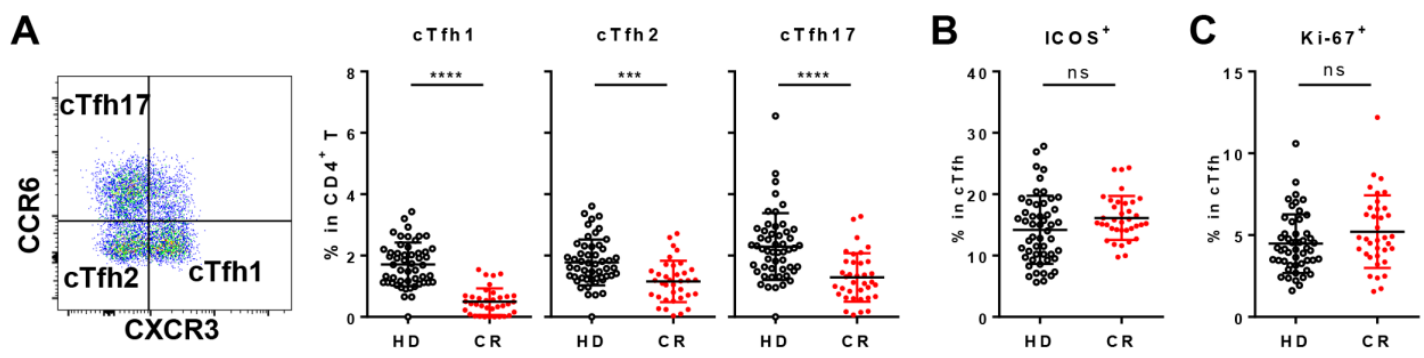

Figure S3. Frequencies of cTfh subsets and the activation, proliferation of cTfh in peripheral

blood of HD and CR. A, Gating strategy and the frequencies of cTfh subsets cTfh1 (CXCR3 ${ }^{+}$ $\left.\mathrm{CCR}^{-}\right)$, cTfh2 (CXCR3 $\left.3^{-} \mathrm{CCR}^{-}\right)$and cTfh17 (CXCR3- $\left.{ }^{-} \mathrm{CRR}^{+}\right)$of $\mathrm{CD}^{+} \mathrm{T}$ cells in PBMCs of healthy donors $(\mathrm{n}=55)$ and clinically recovered COVID-19 individuals (CR). B and C, The frequencies of $\mathrm{ICOS}^{+}$and $\mathrm{Ki}-67^{+}$cells in cTfh. ns, non-significant; ***, p<0.001; ****, $\mathrm{p}<0.0001$.

A
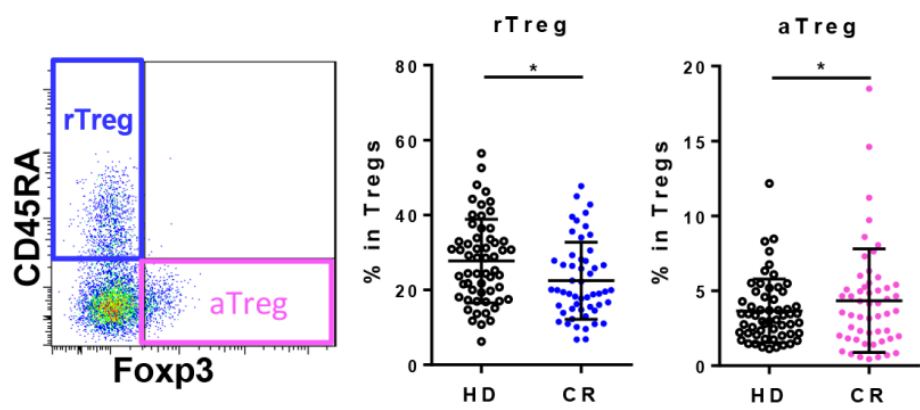

\section{B}
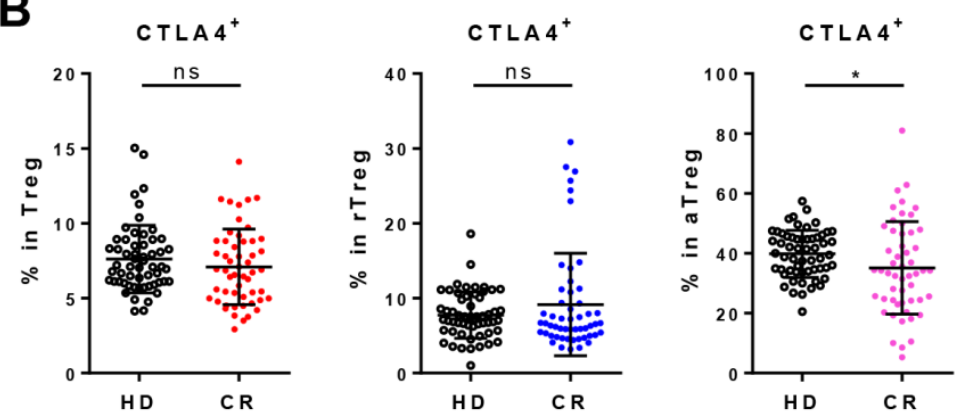

Figure S4. Frequencies and phenotype of Tregs and Treg subsets in peripheral blood of HD and CR. A, Gating strategy and the frequencies of resting Treg (rTeg, CD45RA ${ }^{+} F o x p 3^{\text {lo }}$ ) and activated Treg (aTreg, CD45RAFoxp $3^{\text {hi }}$ ) in Treg. B, The frequencies of CTLA- $4^{+}$cells in Treg, rTreg and aTreg. ns, non-significant; $*, \mathrm{P}<0.05$. 
A



B

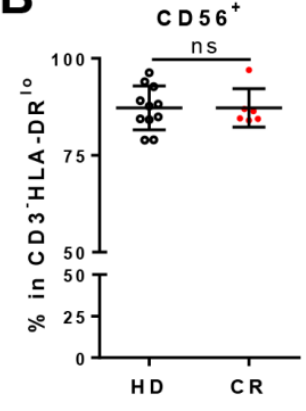

Figure S5. Frequencies of $\mathrm{CD56}^{+} \mathrm{NK}$ cells in $\mathrm{CD3}^{-} \mathrm{HLADR}^{\mathrm{lo}}$ lymphocytes cells of peripheral blood. Gating strategy and the frequencies of $\mathrm{CD} 56^{+} \mathrm{NK}$ cells $\left(\mathrm{CD}^{5} 6^{+} \mathrm{CD} 19^{-}\right)$in $\mathrm{CD}^{-} \mathrm{HLADR}^{\mathrm{lo}}$ lymphocytes of PBMCs derived from $\mathrm{HD}(\mathrm{n}=8)$ and $\mathrm{CR}(\mathrm{n}=5)$. ns, non-significant. 


\section{Supplementary tables}

Supplementary Table 1 (Table S1): clinical information of CR cohort

\begin{tabular}{|c|c|c|c|c|c|c|c|c|c|c|c|c|c|c|c|c|}
\hline \multirow[b]{2}{*}{ final code } & \multirow[b]{2}{*}{$\operatorname{sex}$} & \multirow[b]{2}{*}{ age } & \multirow[b]{2}{*}{ day of discharge } & \multirow[b]{2}{*}{ day of testing } & \multirow{2}{*}{$\begin{array}{l}\text { days post } \\
\text { discharge }\end{array}$} & \multicolumn{2}{|c|}{ SARS-CoV-2 antibody } & \multirow{2}{*}{$\begin{array}{c}\text { blood } \\
\text { oxygen } \\
\text { saturation }\end{array}$} & \multicolumn{5}{|c|}{ symptoms in two weeks } & \multicolumn{3}{|c|}{ blood routine examination $\left(10^{9} / \mathrm{L}\right)$} \\
\hline & & & & & & $\mathrm{IgG}$ & $\operatorname{IgM}$ & & fever & $\begin{array}{l}\text { shod of } \\
\text { breath }\end{array}$ & cough & expectoration & $\begin{array}{l}\text { oxygen } \\
\text { uptake }\end{array}$ & WBC & neutrophils & lymphocytes \\
\hline 1 & M & 43 & 2020-3-17 & $2020-4-14$ & 28 & + & + & 99 & - & - & - & - & - & 6.22 & 3.81 & 1.95 \\
\hline 2 & $\mathrm{~F}$ & 46 & $2020-2-5$ & $2020-4-14$ & 44 & + & + & 99 & - & - & + & - & - & 6.52 & 1.59 & 1.8 \\
\hline 3 & $\mathrm{~F}$ & 50 & $2020-3-13$ & $2020-4-14$ & 32 & + & - & 99 & - & - & - & - & - & 5.54 & 3.66 & 1.33 \\
\hline 4 & M & 68 & $2020-3-12$ & $2020-4-14$ & 39 & + & - & 99 & - & - & - & - & - & 5.68 & 3.47 & 1.91 \\
\hline 5 & $\mathrm{~F}$ & 40 & 2020-3-1 & $2020-4-14$ & 54 & + & + & 99 & - & - & - & - & - & 5.21 & 3.88 & 1.03 \\
\hline 6 & $\mathrm{~F}$ & 48 & $2020-3-2$ & $2020-4-14$ & 73 & + & - & 99 & - & - & - & - & - & 6.06 & 2.71 & 2.94 \\
\hline 7 & $\mathrm{~F}$ & 39 & 2020-3-2 & $2020-4-14$ & 45 & + & + & 98 & - & - & - & - & & 6.26 & 4.12 & 1.64 \\
\hline 8 & M & 45 & $2020-3-13$ & $2020-4-14$ & 61 & + & + & 99 & - & - & - & - & - & 5.06 & 2.64 & 1.81 \\
\hline 9 & M & 60 & $2020-2-28$ & 2020-4-14 & 41 & + & - & 98 & - & - & - & - & - & 3.75 & 2.12 & 1.26 \\
\hline 10 & $\mathrm{~F}$ & 34 & $2020-3-6$ & $2020-4-14$ & 41 & + & - & 98 & - & - & - & - & - & 5.55 & 3.06 & 1.88 \\
\hline 11 & M & 32 & $2020-2-20$ & $2020-4-14$ & 29 & + & - & 95 & - & - & - & - & - & 6.56 & 4.12 & 2.07 \\
\hline 12 & M & 55 & 2020-1-31 & $2020-4-14$ & 32 & + & - & 96 & - & - & - & - & - & 5.33 & 1.9 & 3.01 \\
\hline 13 & $\mathrm{~F}$ & 54 & 2020-2-1 & 2020-4-14 & 38 & + & - & 99 & - & - & - & - & - & 4.78 & 2.85 & 1.48 \\
\hline 14 & M & 35 & 2020-3-5 & $2020-4-14$ & 40 & + & + & 98 & - & - & - & - & - & 6.9 & 3.44 & 2.95 \\
\hline 15 & $\mathrm{~F}$ & 57 & 2020-2-29 & $2020-4-14$ & 41 & + & - & 99 & - & + & - & - & - & 5.69 & 3.15 & 2.01 \\
\hline 16 & $\mathrm{~F}$ & 27 & 2020-3-10 & $2020-4-14$ & 44 & + & - & 99 & - & - & - & - & - & 5.29 & 2.7 & 2.2 \\
\hline 17 & $\mathrm{~F}$ & 31 & $2020-2-13$ & 2020-4-14 & 37 & + & + & 99 & - & - & - & - & - & 6.36 & 3.18 & 2.32 \\
\hline 18 & $\mathrm{~F}$ & 51 & $2020-3-14$ & $2020-4-14$ & 40 & + & + & 99 & - & - & - & - & - & 3.95 & 2.22 & 1.41 \\
\hline
\end{tabular}




\begin{tabular}{|c|c|c|c|c|c|c|c|c|c|c|c|c|c|c|c|c|}
\hline 19 & $\mathrm{~F}$ & 34 & $2020-3-12$ & $2020-4-14$ & 51 & + & + & 98 & - & - & - & - & - & 7.22 & 4.46 & 2.21 \\
\hline 20 & $\mathrm{~F}$ & 68 & 2020-2-14 & 2020-4-14 & 74 & + & + & 99 & - & - & - & - & - & 4.08 & 3.22 & 0.64 \\
\hline 21 & M & 60 & $2020-3-15$ & $2020-4-14$ & 47 & + & + & 99 & - & - & - & - & - & 6.31 & 3.76 & 2.01 \\
\hline 22 & $\mathrm{~F}$ & 31 & $2020-3-17$ & $2020-4-14$ & 55 & + & + & 98 & - & - & - & - & - & 7.24 & 3.45 & 3.12 \\
\hline 23 & $\mathrm{~F}$ & 39 & $2020-2-12$ & $2020-4-14$ & 73 & + & + & 96 & - & - & - & - & - & 6.09 & 3.56 & 2.06 \\
\hline 24 & M & 37 & $2020-2-22$ & $2020-4-15$ & 33 & + & - & 99 & - & - & - & - & - & 6.96 & 4.78 & 1.76 \\
\hline 25 & M & 70 & 2020-3-4 & $2020-4-15$ & 34 & + & - & 98 & - & + & - & - & - & 7.13 & 4.38 & 2.08 \\
\hline 26 & $\mathrm{~F}$ & 51 & $2020-3-18$ & $2020-4-15$ & 44 & + & - & 99 & - & - & - & + & - & 7.98 & 5 & 2.44 \\
\hline 27 & $\mathrm{~F}$ & 40 & 2020-3-1 & $2020-4-15$ & 46 & + & - & 99 & - & - & - & - & - & 5.17 & 3.13 & 1.66 \\
\hline 28 & $\mathrm{~F}$ & 51 & $2020-3-4$ & $2020-4-15$ & 41 & + & - & 99 & - & - & - & - & - & 3.82 & 1.92 & 1.42 \\
\hline 29 & $\mathrm{~F}$ & 61 & $2020-2-22$ & $2020-4-15$ & 36 & + & + & 98 & - & - & - & - & - & 6.85 & 3.74 & 2.39 \\
\hline 30 & $\mathrm{~F}$ & 67 & $2020-3-14$ & $2020-4-15$ & 32 & + & - & 98 & - & + & - & - & - & 7.32 & 3.68 & 2.9 \\
\hline 31 & M & 56 & $2020-3-18$ & $2020-4-15$ & 34 & + & + & 99 & - & - & - & - & - & 7.96 & 4.81 & 2.5 \\
\hline 32 & M & 51 & $2020-3-16$ & $2020-4-15$ & 63 & + & - & 98 & - & - & - & - & - & 8.58 & 6.74 & 1.38 \\
\hline 33 & $\mathrm{~F}$ & 61 & $2020-3-6$ & $2020-4-15$ & 28 & + & + & 98 & - & - & - & - & - & 6.13 & 3.43 & 2.15 \\
\hline 34 & M & 31 & $2020-2-25$ & 2020-4-15 & 53 & + & - & 98 & - & - & + & - & - & 6.38 & 4.06 & 2.01 \\
\hline 35 & M & 53 & $2020-2-10$ & $2020-4-15$ & 40 & + & + & 99 & - & - & - & - & - & 5.19 & 2.86 & 2 \\
\hline 36 & $\mathrm{~F}$ & 38 & $2020-3-13$ & $2020-4-15$ & 50 & + & - & 99 & - & - & - & - & - & 5.02 & 2.78 & 1.87 \\
\hline 37 & $\mathrm{~F}$ & 40 & 2020-3-7 & $2020-4-15$ & 65 & + & - & 99 & - & - & - & - & - & 5.49 & 2.8 & 2.33 \\
\hline 38 & M & 54 & 2020-3-5 & 2020-4-15 & 51 & + & - & 96 & - & - & - & - & - & 5.15 & 2.79 & 1.9 \\
\hline 39 & $\mathrm{~F}$ & 56 & $2020-2-24$ & $2020-4-15$ & 33 & + & - & 98 & - & - & - & - & + & 6.11 & 3.43 & 1.97 \\
\hline 40 & $\mathrm{~F}$ & 38 & $2020-3-4$ & $2020-4-15$ & 49 & + & + & 99 & - & - & - & - & - & 4.88 & 2.38 & 2.07 \\
\hline 41 & $\mathrm{~F}$ & 43 & 2020-3-1 & $2020-4-15$ & 52 & + & - & 99 & - & - & - & - & - & 8.86 & 5.14 & 3.09 \\
\hline 42 & $\mathrm{~F}$ & 57 & $2020-2-23$ & $2020-4-16$ & 71 & + & + & 99 & - & - & + & - & - & 6.02 & 3.67 & 1.94 \\
\hline 43 & M & 34 & $2020-3-13$ & $2020-4-16$ & 45 & + & - & 99 & - & - & + & - & - & 3.97 & 2.06 & 1.6 \\
\hline
\end{tabular}




\begin{tabular}{|c|c|c|c|c|c|c|c|c|c|c|c|c|c|c|c|c|}
\hline 44 & $\mathrm{~F}$ & 61 & $2020-3-8$ & $2020-4-16$ & 76 & + & - & 99 & - & - & + & + & - & 4.98 & 3.24 & 1.4 \\
\hline 45 & $\mathrm{~F}$ & 57 & $2020-3-5$ & $2020-4-16$ & 62 & + & - & 99 & - & - & - & - & - & 6.63 & 4.71 & 1.45 \\
\hline 46 & M & 55 & $2020-2-23$ & $2020-4-16$ & 32 & + & - & 96 & - & + & + & + & - & 7.17 & 5.34 & 1.37 \\
\hline 47 & M & 51 & $2020-2-26$ & $2020-4-16$ & 30 & + & - & 99 & - & - & - & - & - & 4.56 & 2.46 & 1.54 \\
\hline 48 & M & 38 & 2020-3-14 & $2020-4-16$ & 54 & + & - & 99 & - & - & - & - & - & 6.1 & 3.8 & 1.82 \\
\hline 49 & $\mathrm{~F}$ & 51 & $2020-2-26$ & $2020-4-16$ & 46 & + & + & 99 & - & - & - & - & - & 4.88 & 2.82 & 1.54 \\
\hline 50 & M & 56 & $2020-3-17$ & $2020-4-16$ & 33 & + & - & 96 & - & - & - & - & - & 5.24 & 2.17 & 2.63 \\
\hline 51 & $\mathrm{M}$ & 61 & $2020-1-31$ & $2020-4-16$ & 29 & + & + & 99 & - & - & - & - & - & 3.93 & 1.83 & 1.75 \\
\hline 52 & $\mathrm{~F}$ & 39 & $2020-2-27$ & 2020-4-16 & 53 & + & - & 99 & - & - & - & - & - & 5.32 & 4.94 & 3.61 \\
\hline 53 & $\mathrm{~F}$ & 52 & 2020-2-19 & $2020-4-16$ & 50 & + & - & 99 & - & - & - & - & - & 6.66 & 3.67 & 2.56 \\
\hline 54 & $\mathrm{~F}$ & 70 & $2020-2-1$ & 2020-4-16 & 33 & + & - & 99 & - & - & - & - & - & 5.57 & 3.18 & 1.9 \\
\hline 55 & $\mathrm{~F}$ & 65 & $2020-2-23$ & $2020-4-16$ & 30 & + & - & 99 & - & - & - & - & - & 5.46 & 2.94 & 2.1 \\
\hline
\end{tabular}

+ , positive; -, negative.

Cells filled in yellow color means the value was higher than normal range while cells filled in blue color means the value was lower than normal range 
medRxiv preprint doi: https://doi.org/10.1101/2020.07.01.20144030; this version posted July 2, 2020. The copyright holder for this preprint (which was not certified by peer review) is the author/funder, who has granted medRxiv a license to display the preprint in perpetuity.

All rights reserved. No reuse allowed without permission.

Supplementary Table 2 (Table S2): reagents for flow cytometry

\begin{tabular}{|c|c|c|c|}
\hline antibodies (clone) & $\begin{array}{l}\text { staining } \\
\text { procedure }\end{array}$ & source & identifier \\
\hline Fixable Viability Dye eFluor ${ }^{\mathrm{TM}} 506$ & surface & eBioscience & $65-0866-14$ \\
\hline Alexa Fluor® 700 anti-human CD183 (CXCR3) (G025H7) & surface & BioLegend & 353742 \\
\hline Alexa Fluor ${ }^{\circledR} 700$ anti-human CD3 (SK7) & surface & BioLegend & 344822 \\
\hline Alexa Fluor ${ }^{\circledR} 700$ anti-human CD4 (OKT4) & surface & BioLegend & 317426 \\
\hline APC anti-human CD196 (CCR6) (G034E3) & surface & BioLegend & 353416 \\
\hline APC anti-human CD275 (B7-H2, ICOSL) (2D3) & surface & BioLegend & 309408 \\
\hline APC/Cyanine7 anti-human CD3 (HIT3a) & surface & BioLegend & 300318 \\
\hline APC/Cyanine7 anti-human CD45RA (HI100) & surface & BioLegend & 304127 \\
\hline Brilliant Violet 421 ${ }^{\mathrm{TM}}$ anti-human/mouse/rat CD278 (ICOS)(C398.4A) & surface & BioLegend & 313524 \\
\hline Brilliant Violet $605^{\mathrm{TM}}$ anti-human CD19 (HIB19) & surface & BioLegend & 302244 \\
\hline Brilliant Violet $605^{\mathrm{TM}}$ anti-human CD8a (RPA-T8) & surface & BioLegend & 301040 \\
\hline Brilliant Violet $650^{\mathrm{TM}}$ anti-human CD38 (HB-7) & surface & BioLegend & 356620 \\
\hline Brilliant Violet $650^{\mathrm{TM}}$ anti-human CD4 (RPA-T4) & surface & BioLegend & 300536 \\
\hline FITC anti-human CD20 (2H7) & surface & BioLegend & 302304 \\
\hline FITC anti-human CD25 (BC96) & surface & BioLegend & 302604 \\
\hline FITC anti-human CD45RO (UCHL1) & surface & BioLegend & 304242 \\
\hline Pacific Blue ${ }^{\mathrm{TM}}$ anti-human CD27 ( O323) & surface & BioLegend & 302822 \\
\hline PE anti-human IgM (MHM-88) & surface & BioLegend & 314508 \\
\hline PE/Cy7 anti-human CTLA-4 (L3D10) & surface & BioLegend & 349914 \\
\hline PE/Cyanine7 anti-human CD27 (O323) & surface & BioLegend & 302838 \\
\hline PE/Dazzle ${ }^{\mathrm{TM}} 594$ anti-human CD279 (PD-1 (EH12.2H7) & surface & BioLegend & 329940 \\
\hline PE/Dazzle ${ }^{\mathrm{TM}} 594$ anti-human CD71 (CY1G4) & surface & BioLegend & 334120 \\
\hline PerCP/Cy5.5 anti-human CD127 (A019D5) & surface & BioLegend & 351322 \\
\hline PerCP/Cyanine5.5 anti-human CD185 (CXCR5) (J252D4) & surface & BioLegend & 356910 \\
\hline PerCP/Cyanine5.5 anti-human HLA-DR (L243) & surface & BioLegend & 307630 \\
\hline Brilliant Violet 421 $1^{\mathrm{TM}}$ anti-human FoxP3 (206D) & intracellular & BioLegend & 320124 \\
\hline Brilliant Violet $650^{\mathrm{TM}}$ anti-human IL-2 (MQ1-17H12) & intracellular & BioLegend & 500334 \\
\hline FITC anti-human/mouse Granzyme B (QA16A02) & intracellular & BioLegend & 372206 \\
\hline PE anti-human IL-21 (3A3-N2) & intracellular & BioLegend & 513004 \\
\hline PE anti-human Ki-67 (Ki-67) & intracellular & BioLegend & 350504 \\
\hline PE/Cy7 anti-human IL-4 (MP4-25D2 ) & intracellular & BioLegend & 500824 \\
\hline PE/Cyanine7 anti-human Ki-67 ( Ki-67) & intracellular & BioLegend & 350526 \\
\hline PE/DazzleTM 594 anti-human IFN- $\gamma$ (B27) & intracellular & BioLegend & 506530 \\
\hline PerCP/Cy5.5 anti-human IL-17A (BL168) & intracellular & BioLegend & 512314 \\
\hline
\end{tabular}

